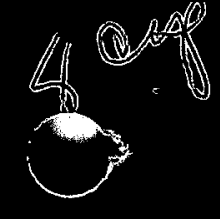

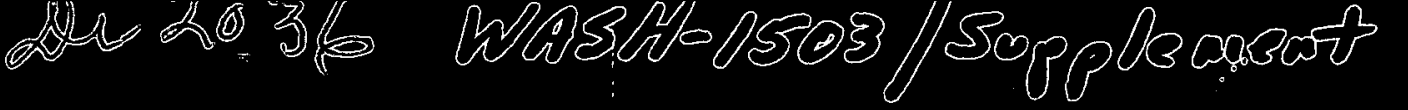

\title{
SUPPLE EN
}

T(10. THR

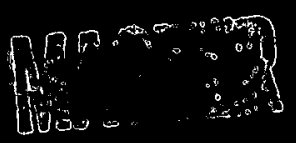

RADUOACTIVE WASTE MEPOSUIORY

$\angle Y \cap \mathbb{N S} S_{0}, K A N S A S$

JULY 1970

UNDITED STATES ATOMDC ENEERGY, COMMUSS RON

WASHINGTONOD。CO20545

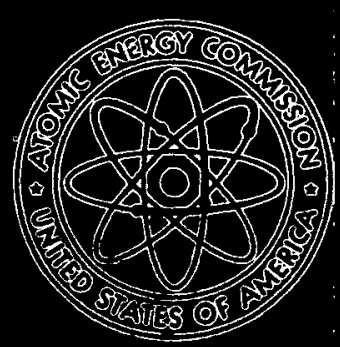




\section{DISCLAIMER}

This report was prepared as an account of work sponsored by an agency of the United States Government. Neither the United States Government nor any agency Thereof, nor any of their employees, makes any warranty, express or implied, or assumes any legal liability or responsibility for the accuracy, completeness, or usefulness of any information, apparatus, product, or process disclosed, or represents that its use would not infringe privately owned rights. Reference herein to any specific commercial product, process, or service by trade name, trademark, manufacturer, or otherwise does not necessarily constitute or imply its endorsement, recommendation, or favoring by the United States Government or any agency thereof. The views and opinions of authors expressed herein do not necessarily state or reflect those of the United States Government or any agency thereof. 


\section{DISCLAIMER}

Portions of this document may be illegible in electronic image products. Images are produced from the best available original document. 
X. Bibliography

73. Public Works for Water, Pollution Control and Power Development and AEC Appropriation Bil1, 1971. Hearings before the Public Works Subcommittee of the Committee on Appropriations, House of Representatives, May 26, 1971, pp. 1319-1334

\section{NOTICE}

This report was prepared as an account of work sponsored by the United States Government. Neither the United States nor the United States Atomic Energy Commission, nor any of their employees, nor any of their contractors, subcontractors, or their employees, makes any warranty, express or implied, or assumes any legal liability or responsibility for the accuracy, completeness or usefulness of any information, apparatus, product or process disclosed, or represents that its use would not infringe privately owned rights.

This document is

PUBLICLY RELEASABLE
$\frac{B S E \text { oolo }}{\text { Authorizing Official }}$
Date $5 / 11 / 07$

- 101a- 


\section{$\begin{array}{llllll}\text { A } & \mathrm{N} & \mathrm{N} & \mathrm{E} & \mathrm{X} & \mathrm{I}\end{array}$}

\section{APPENDIX}

Exchange of Correspondence Between

Representative Joe Skubitz, 5th District, Kansas

and the

Atomic Energy Commission 


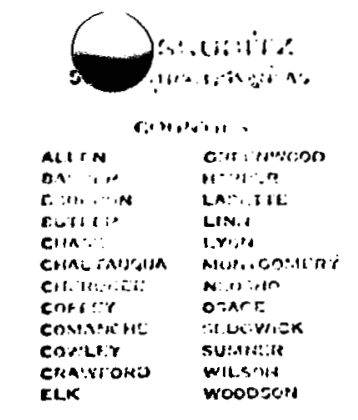

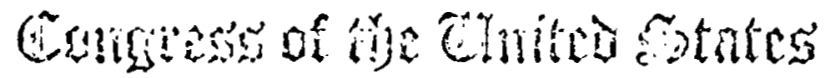

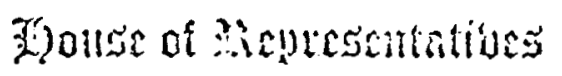

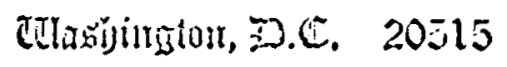

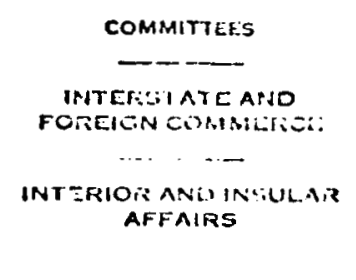

June 22, 1971

Dear Mr. Erlewine:

Thank you for your June 18 reply to my letter of June. 10 .

You seem to miss the thrust, and certainly the spirit, of my inquiry, i.e., that the AEC selected those comnonts on its Draft statement that it preferred to handle in its Final statement. You rely on technicalities - that the sen. Dole letter specified that it could scrve as a "comment" on the Draft statement even though it was primarily intended as testimony for the hearings record; that the Governor Docking letter (of Feb. 22) said it was a response to an invitatjon from the $\triangle E C$ to comment on the Draft statement.

Of course, no one can refute these legal niceiies. I had thought good conscience and good morals and a cesire on the part of a Government agency to deal with the iacts as they are and not as it can manage thein, would have induced the AEC to take cognizance of the three Jatter. letters of Governor Docking. After all, he is the Governor of the state and has some degree of responsibility and authority, as Chairman Pastore put it, as to what happens in his state. The AEC has a ciuty to not only apprise itself of his current comment but to deal with it.

I tried to make the same point with respect to the final. Hambletion and Halepaska letters to the Appropriations Committee and the reference to the viewpojints of the forty scientists assembled by them to give serious and meaningful consideration to the AEC's proposal. of course, you can legally ignore those comments and the current Docking viewpoints, but in so doing, you are not facing the issie. You are ducking it on a legal 
technicality although, as I pointed out in my June 10 letter, one would assume the AEC would be eager to face up to the hardest questions and comments.

It is passing strange that you would select out such an item as a late-dated press release from Kansas University that has absolutely no relation to the Draft Environmental statement except that you could make it convey that scientific differences have been patched up. But almost concurrent letters to the Joint Committee from Drs. Hambleton and Halepaska that tell a different story and highlight and emphasize what the AEC must yet do are blithely ignored.

Your measuring stick of what to include and what to exclude is that marvelously ambiguous sentence: "A few of these are referred to or included as a part of AEC's responses to comments on the Draft Environmental Statement in an effort to clarify action taken on a comment or to indicate progress made on a given issue." (Emphasis supplied.)

Obviously, Mr. Erlewine, neither the AEC's final Enviromental. Statement nor its substantial propaganda campaign has convinced everybody, by any means, that the AEC is on the right track or even that your agency is to be completely trusted. For example, a year ago The Wichita Eagle and Beacon, the largest newspaper in Kansas, in a lead editorial in its July 30, 1970 edition cautioned me, as the then leading critic of the waste depository, to "Rest Easy Rep. Skubitz, Precautions Are Being Taken." It suggested that your agency was on the right track and all would work out well.

But what does it say now, one year later? On June 12, 1971, again in the lead editorial, The Eagle writes: "Its Time to Be Sure on Lyons Repository." In a particularly significant paragraph, it recommends:

"And that's why the Kansas congressional delegation should be exerting every effort to prevent the Atomic Energy Commission (AEC) from gaining title to the 1,000-acre site 
it wants until all the doubts are laid to rest."

I'm enclosing copies of the full text of both editorials for your information.

In my judgement, you should indeed, as you have offered to do, prepare and distribute a supplement to the Appendix to contain and include not alone the full text of my correspondence with the AEC, but also each and every pertinent comment made by each and every addressee listed by you, to or about the atomic waste depository to $A E C$ and to the cognizant congressional committees dealing with the project. Specifically, I mean that you should include all of the letters of Governor Docking to the Joint Committee and the Appropriations Conmittee; ail of the letters of Drs. Hambleton and Halepaska to the Joint Committee and the Appropriations committee, the testimony and or statements of senator Pearson, Reps. Roy, Sebelius, Shriver, and of myself to the Joint Committee and to the Appropriations Committee.

Each and every one of those letters and statements are directed at the Draft Environmental statement, whether or not so addressed specifically. They deal with the waste disposal facility and the AEC's standards for it and as a responsible agency you may have the legal but not the moral right to ignore them.

You close by "regretting" that I am not satisfied with your efforts to fulfill your legislative responsibility. Of course, I am not satisfied because throughout you have attempted to cut and run; to carry out a previously adopted decision to install the waste dump regardless of the scientific facts that might be developed to alter or modify such a decision; to use legal technicalities and scientific verbiage in an effort to confuse and mislead non-scientifically educated persons. 
All in all, your's has been a shabby endeavor in this instance, not befitting any Federal agency much less one supposedly dedicated to the scientific truth and therefore not afraid to face facts. Of course, I am disappointed and dissatisfied with the $A E C$ and I am far from alone in the congress in so believing.

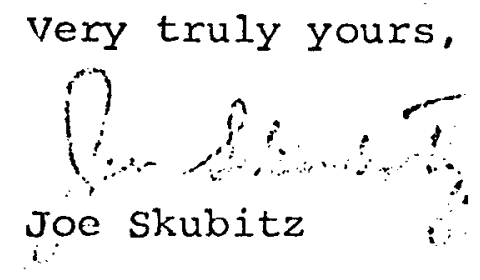

Mr. John A. Erlewine

Assistant General Manager for

Operations

Atomic Energy Commission

washington, D. C. 20545

Enclosure

cc: Members Joint Comittee on Atomic Energy

Members Public Works subconmittee of the

House Appropriations Committee

Honorable Robert B. Docking

Honorable Robert J. Dole

Honorable James B. Pearson

Honorable William Roy

Honorable Keith Sebelius

Honorable Garner Shriver

Honorable Larry winn

Dr. William W. Hambleton 


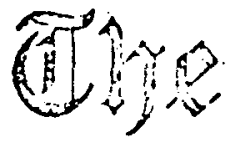

Marsh Piurdcok

Choirman of the Board

Eritt Brown

Vice President and Secretary

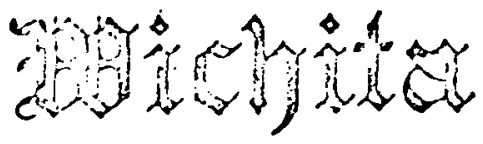

Marcellus M. Murdock

$(1883-1970)$

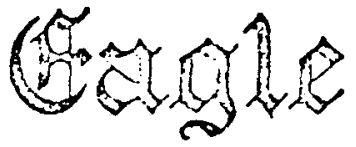

Victor Delano

President and Treasurer

Founded in 1872 by Marshall M. Murdesh

John H. Colburn

Editor and Publisher

Pağ iA EDITORIAL OPINION PACE Thursday, July 30, 1970

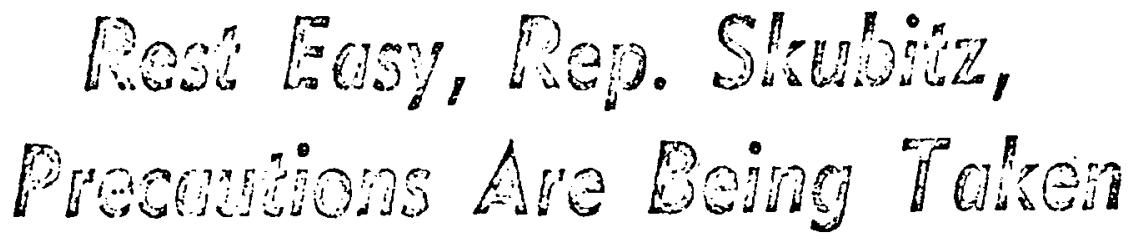

Fen. Joe Skubity, R-Kan., is right to the crincerned ahoilt the welfare of the people of Lyons, Kan, even though they aren't in his district.

However, he can be reassured that proper precautions are being tation to safeguard them from exposure fo radiation. A phlilic heariug at Lyons Wodnesda: was aimed at easing the minds of Ined residents.

Skubitz, who represents the Fifth District, mostly in Sonti:east Kansas, urged the cinaiman of tha Atomic Energy Conmission the other day to explain "the exact nature of the risks and dangers" involued in a recent proposal to bury atomic wastes in a i.yons sait mine.

Uniortunately, this can't bo done easily. Somo testing with simulated atoric wastes has been dono at the Carey Salt mine in ITutchinson, and preliminary : findings incicate storago in salt beds is ieasible.

Nevertheless, thero aro many questions to be answered before the government can say flaily that it is absolutely safe.

That is why the U. S. Genlngical Suiry aur? the Kansas State Genlogical surecy will thoroughin test the Lyons site before the Atnmic Energy Conmission is given a go-ahead on constru :ion.

A proliminary safety analysis is to be given tho AEC by Nor. 15, a date that Skubitz. has said is ton soon. Rut ifficials at the Kancas State Departmenit of Health $s a j$ this is by no means fina!

Bob Will, hearl of the state hraih department's radinlogical bealth unit of the Finvironmentas Control Jjivision, told the Earge's editurial pago recently that it would be at least two yeals bofnle construction could begin cren if the geological surveys were to give a green light.

In addition, the health department has assigned a man full-time to monitoring the en:'re Lyons operation, and if lie finds anything harmful at any time, the department will act.

The AEC, Will said, has assured the state through the National Academy of Sciences that after tho operation begins (if it does), if anything is found harmful to people or property, the opelation will cease.

As of now, health department officials think the storage program is feasible. But this is based upon prolim ary test results and can be modified as new evidence is turned up. 


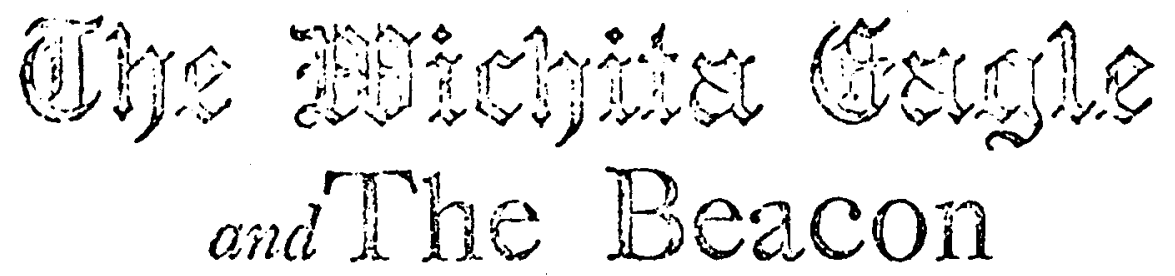

Marsh Murdocix Marcelius M. Murdock
Chairman of thie Beaid $(1883-1970)$
Britt Brown

Founded in 1872 by Marshall M. Murdock

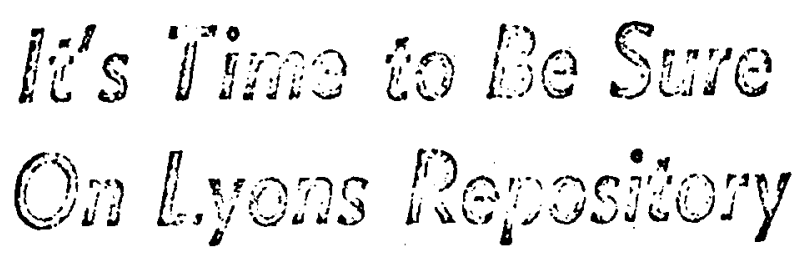

No one wants to be inational about the proposed nuclea: wasto depository at Iyons. Lut certainiy every gunsan should bo concenec about it unit there is absolute gesurance of tire safety of the installation. That assurarico does not as yet exist.

And linat's why the ransas congressomat delegaion should be exaltires ereng elinit o prevent the Alwite Energ Commisson (AEC) from gan-

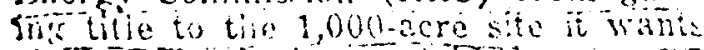
uncil an the doubis and lair to rest.

The trouble with fecieral agencies is that once the $y$ have geguired land liney iend to eon miti their projects, no matter what. The depositins of radioRctive waste in the salt beds is far too -if $f y$ a proposition to be permitica to happen withuut adequate investiration.

In its report joved Wednesday, AFC said some of its findings indicato there would be "mino: enviroumental $\mathrm{e} f$ fects at the site and beyond."

That of itsolf scems reason elourh to ine ist upon further ani more comilete testing before a decision is made.

In faimess to ACC it must be sairl that it lass requestid 51 million now tor

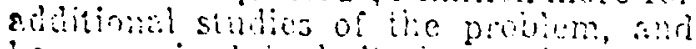

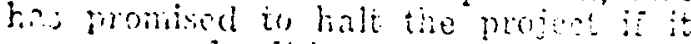

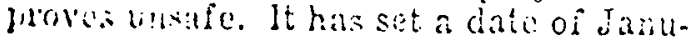

ary, 1075, to begin the deposit of "low, low waste" which is contiminated clothing and things of tinat sort, and January. 1976 , as the date for the rea!ly "hot" waste, proviced it is satiofied with the results of the further testing.

That is somewhat reassuring. Pibt not only AEC but also kansas scientisi.x should be satisiied if the safety of t? project before any goditional nioves toward its establishment are nade.

Many of the people at Iryons vilo farome revositur losent the interierenced doveracr hocking the Kansas Genlorical Surves, snd others in the mitier. Jut the ir motives are of the

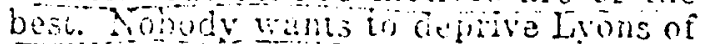
an installatiou thotwionovirejnos am possibly other benerits if these is no denirer to that conmunity or any other from it.

But there are unanswered qucstions about underground water, the effects of the heat upon the sait, the possibility of geological faults beneath o, $n$ a a the salt beds, and many othor things. The tesling that has been done thus fail is judged by o ur Kansas scientisis to be oversimplified.

Wo're dealing witis ons ilutule irr

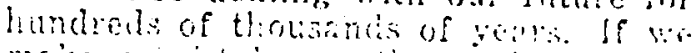

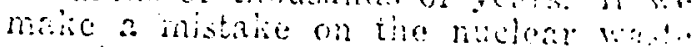

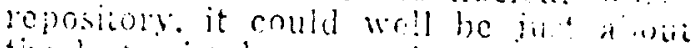
the last mistake we make. 


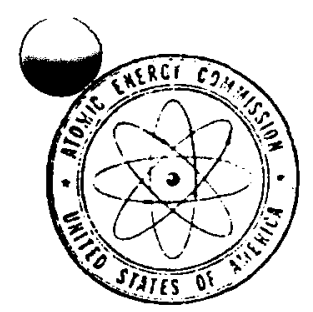

UNITED STATES

ATOMIC ENERG' COMMISSION

WASHINGTON, D.C. 20545

June is, 1971

Honorable Joe Skubitz

House of Representatives

Dear Mr. Skubitz:

This is in response to your letter of June 10 in which you question the basis for the AEC salection of comments for inclusion in the Final Environmental Statement on the Radioactive Waste Repository in Lyons, Kansas.

The Draft Environmental Statement was published and distributed pursuant to the Council on Environmental Quality's (CEQ) interim guidelines which were issued to inplement the National Environmental Policy Act of 1969 (NEPA). The CEQ interim guideiines require soliciting comments from Federal, state and local agencies "authorized to develop and enforce environmental standards." Attached is a listing of the organizations and persons to whom the Draft Environmental Statement was sent for coment. A11 comments on the Draft Statement are included in the Appendix to the Final Environmenta? Statement. The AEC made no attenpt to exclude any coninents addressed to the Draft Environmental Statement because of their source or content or for any other reason.

There have been many nerspaper articles, items of correspondence, records of testimony and other documents concerning the proposed Radioactive Vaste Repository project which are not addressed to the Draft Environmental Statement on the project and consequently were not included as comments on that document. A few of these are referred to or included as a part of AEC's responses to comments on the Draft Environmental Statement in an effort to clarify action taken on a comment or to indicate progress made on a given issue.

Senator Robert Dole's letter of March 29 referred to the Draft Statement and upon inquiry we were advised that he considered his statement before the Joint Comittee on Atomic Energy (JCAE) as a comment on the Draft Environmental Statement. Senator Randolph's letter with enclosures was incorporated into Senator Dole's statement before the JCAE and we were requested by his Legislative Assistant, Mr. Ward H. White, to consider them part of his comments on the Draft Statement. Mr. White transmitted 
copies of Senator Randolph's letter with enclosures. Governor Docking's letter commenting on the Draft Environmental Statement, and all attachments to the Governor's letter, have been included with the Final Environmental Statement.

Our records indicate that you never responded to my letter of December 17 , 1970, transmitting the Draft Environmental Statement for comment. It is quite true, as your letter. states, that you had raised questions and objections regarding the project prior to receipt of the Draft Environmental Statement. It is also true that every letter you have addressed to the AEC regarding this project has been answered and every effort made to supply requested information. If you wish, we will be happy to issue as a supplement to the Appendix of the Final Environmental Statement, the full text of all correspondence between yourself and the AEC concerning the Repository project.

We are of the opinion that we have responded to all comments on the Draft Environmental Statement and that the Final Environmental Statement is responsive to both the spirit and the letter of NEPA.

We regret that you are not satisfied with our efforts to fulfill our legislative responsibility.

Enclosure:

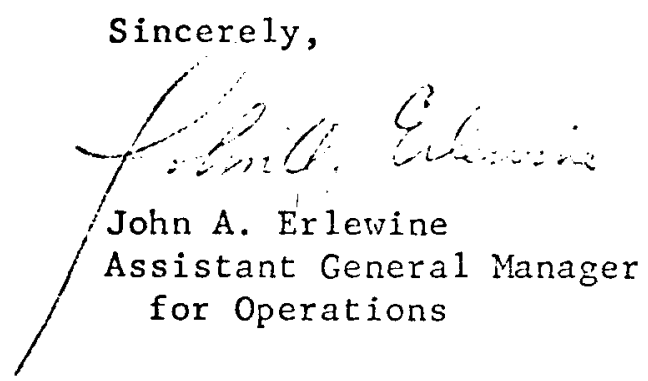

List of Addressees

cc: Members, Joint Comittee on Atomic Energy

Members, Public Wor's Subcomittee of House Appropriations Comittee

Honorable Robert B. Docking

Honorable Robert J. Dole

Dr. William W. Hambleton 
Eederal Agencies

Department of Health, Education and Welfare

Department of the Interior

Department of Transportation

Department of Commerce

Council on Environmental Quality

Office of Management and Budget

Environmental Protection Agency

State

Honorable Robert B. Docking

Governor of Kansas

\section{Congressiona 1}

Honorable James B. Pearson

Honorable Robert J. Dole

Honorable Mike Cravel

Honorable Keith G. Sebelius

Honorable Chester L. Mize

Honorable Larry Winn, Jr.

Honorable Garner E. Shriver

Honorable Joe Skubitz

Mr. Edward J. Bauser

Joint Committee on Atomic Energy

Mr. Kenneth Bousquet

Senate Committee on Appropriations

Mr. Eugene B. Wilhelm

House Committee on Appropriations

\section{Other}

Southern Interstate Nuclear Board

National Academy of Sciences

Western Interstate Nuclear Board 
Dear Mr. Erlewine:

Receipt is acknowledged of the final, I presume, Environmental statement of the Atomic Energy commission on the Lyons Waste Repository, under cover of a letter from your Mr. Samuel L. Hack? Thank you for including me on the list of recipients.

Obviously I have not yet had time to carefully analyze the now expanded 101 pages of the statement from its original 54 pages to understand just how the AEC meets the critical comments of Federal and state agencies and of obviously selected private individuals. I have, however, gone through the 150 pages of Appendix material containing these comments.

Two questions come immediately to mind: 1 . What was the basis for AEC selection of the comments of certain individuals for inclusion in the Appendix? 2. Why were certain statements of included individuals used and other, later statements ignored?

Allow me to amplify. I presume the basis for inclusion in the Appendix is that the material is an official comment on the Draft statement. This raises the question of whether or not all comments (required by the National Environmental policy Act) were considered for inclusion and whether the "complete" comments should not be included.

obiously, I am not suggesting that "complete" means full text so much as it means an equitable, honest reflection of the commentator's position. For example, if Governor Docking raises certain questions in a letter of Feb. 22 and then supplements those comments and questions with more extensive, more precise, and more critical comments in subsequent letters of which you are aware, should not Governor Docking's most current views be more precisely stated rather than allow the impression to be gained that his Feb. 22 letter is his current and latest position? 
Surely the Governor's letters of March 19. and April 28 and of May 21 are as much to be considered "comments" within the meaning of the National Environmental policy Act as was the Statement of Senator Robert J. Dole to the Joint Committee on Atomic Energy on March 16. You found it appropriate to respond to the Dole statement and also to comments furnished to you by the clerk of the senate Public Works committee that he had obtained from six scientists. The latter's comments were, as you know, merely letter-responses addressed to the clerk of the Public Works committee.

I note, by way of another example, that the April 26 letters of $\mathrm{Dr}$. Hambleton and $\mathrm{Dr}$. Halepaska to the congressional committees, with copies to the AEC, are not included. But earlier, less critical comments from these two scientists are made the basis for your responses. Great care is taken by you to include, for example, a late April press release from Kansas University telling of a conference of some forty scientists with the clear inference that the conference resolved existing problems. Again, the inference to the reader is that if there ever were differences between the Kansas scientific community and the AEC, they have been patched over and are no longer important.

But the specific, simultaneous April 26 statements to the Joint Committee on Atomic Energy and the House Appropriations committee from the two Kansas scientists, summarizing the agreedupon position of these forty scientists and emphasizing a basic disagreement with AEC's position are missing. Only the omission of the May 21 Governor Docking letter can be justified by you on the basis that you went to "press" before that date.

I appreciate your reluctance to interpret my testimony before either the Joint committee or the Appropriations committee as "comment" on the Draft Environmental statement, even though Senator Dole's testimony appeared to so qualify. What then was the measuring stick for omitting, for example, my March 1 , 1971 letter to Dr. Seaborg (in response to his unsolicited comments on the Docking letter) in which I sought to outline my objections to the Lyons project? 
My point here is not to justify including the skubitz testimony in summary or as comments. It is rather that if the AEC may selectively choose whom and to what it desires to respond and ignore other comments, it is slanting its case and trying to sell the issue on incomplete testimony. If you have done that with Skubitz, and with Governor Docking, you may well have done it with others. If the AEC case is a strong one certainly it need not dodge the comments of its strongest and most abrasive critics. After all, my objections and my questic predate even your Draft statement and yet remain to be answerec

In summary, may I say that I am shocked that an agency of this Government, however powerful and however "arrogant", as Governor Docking described your actions, should stoop to such evasion. Your actions in this case are reprehensible because they are clearly not inadvertent. That you are prideful and over-weening is obvious; that this should lead you to being misleading and deceitful is almost beyond belief.

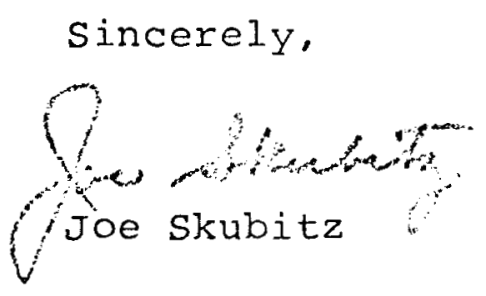

Mr. John A. Erlewine

Assistant General Manager

Atomic Energy Commission

Washington, D. C. 20545

cc: Members Joint Committee on Atomic Energy

Members Public Works subcommittee of House

Appropriations committee

Honorable Robert B. Docking

Honorable Robert J. Dole

Dr. William W. Hambleton 


\author{
UNITIU STATES \\ ATOMIO ENEPE: COMMISSION \\ WASHINGTON. D.C. 20545
}

HAR 241971

Honorable Joc Skubltz

louse of Representatives

Dear Mr. Skubitz:

In your letter of March 1, 1971, you express concern that you have not received the fanal report of the Xansas Gcological

survey. I wish to assure you tint the final report by the state Geological Survey wil te wade available to you as soon as it is publisined. Oux information from the Survey is that this repo: Is in the fiurl preparation stage but will not be transmitted co the Oak ridge fiational lajoratory carlicr tinan next week. Thia report wili be rade available to the Governor and state officialo of Kanses at the same time.

With iegrard to the questiors raised in the Decenber 2, 1970:

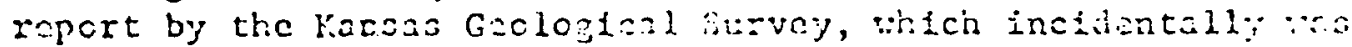

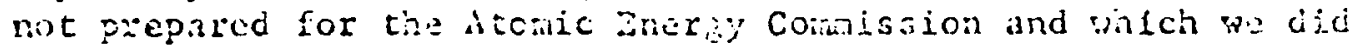
:ot receive until aiter its zecsut mention in the press, i vouid

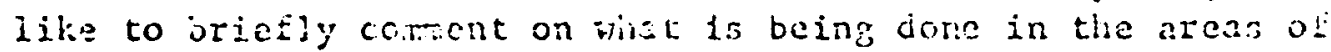
consezn regarcing heat-tiow and the metanict effect. Witi regird to ient-flow, it is recojnized chat the models that have been uscs to datc to calculate tempartures in and arowid the mine

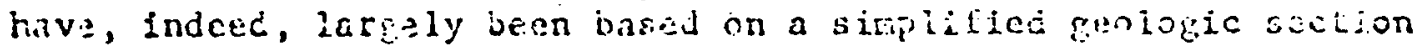
invoiving pure sait and pure shrid beda givis has been nacosiary because tinc detailed zoologic section and the appopzicte thatai

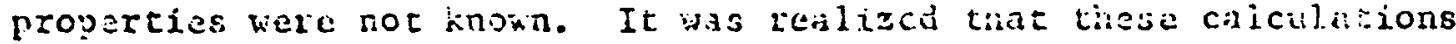
would have to be radue after tire site core drilldas tad suritied the cetalled feolopic section, and the trun thasul propertie:

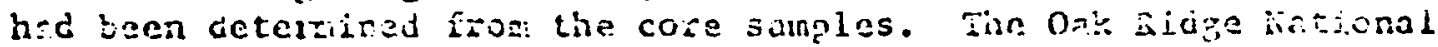
Lubovatory is row engrged in planniag an estensive and dotailcd scrles of heat-filo ciiculations buticd on a ruch more realistic chprosimaticn of tire setual jeologic conditions. Furthernore, arrangemente have beer dade with the U.S. Geological Survey to perfoim ccrtain similar calculations as an independent confirm?tion of the computational techriques. 
With respect to energy storage from radiation damage, the Oak Ridge National Laboratory has zecently completed an analysis of this phenomenon in cooperation with Dr. E. J. Zeller of the University of Kansas. A report will be issued shortly which concludes that there will be no melting of salt and the temperature of salt at a distance of five feet from the container will rise less than $10^{\circ} \mathrm{F}$. The consequences of thermal shock from such an event appear to be negligible. Additional work on the question of stored energy in the solidified waste will be undertaken jointly with Dr. Teller.

Your letter of March 1 also included a number of questions which have been discussed in carlier correspondence or were covered at the llarch 17,1971 hearings. For that reason, we have not attempted to restate the AEC position. We will, however, continue to provide you with reports and information as they become avallable.

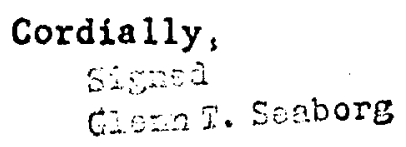

Chairman 
Fronse of Aicpressntatives

Ulasbington, Ð.C. 20515
Information $x \geqslant e$

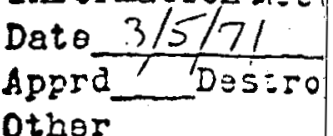

Other

yel Itea

March 1. 1971

Dear Doctor Seaborg:

I must assume that you are individually responsible for your letter of february 23 while members of your stafi prepared tine 7-page addendum. While I am not surprised with the bureaucratic doubletalk, the orrellian jergon that war is peace, that permeates the attachnent, I am chagrined and disappointed with your oun letter. If this is the kind of answer that a Member of congress seeking specific and unambiguous answers to his questions receives from so eminent an agency head as you are, it is obvious why the AEC waste depository plan has becone suspect and why Kansas citizens must become increasingly wary of AEC machinations.

since I am not a scientist, nor knowledgeable in atomic matters, nor have the benefit of a large, highly qualizied stä to guide me, my comments will lack the sophistication of one nuclear physicist writing to another. I shall, as a layman, hoirever patiently attempt to deal with your letter and its at tachment.

I have, of course, relied on scientific authorities for certain zacts and observations. Most inpressive to me is the Depantment of the Interior's 6page analysis of $2 E C^{\prime} s$ dxati envircnmental report for the questions it raises. Cthers include one of your contractors, Dr. Willizn Harbleton o Fine kansas Stata Geological Survey, Dr. Nalicr heyer, professor of nuclear engineering at Kansas state University, and $R$. $E$. Tonlinson, manager o $0=30250$ h and development for Atlantic-nichEisli at tho yanford Atomic works. 
Let me emphasize first and last that the fundamental isslie is not a scientific one of whether the AEC can prove that nuclear wastes are dangerous or not; of whether the AEC can prove that the lyons salt beds are a "safe" repositury or not; or indeed of whether the waste durnp is a matter of national public interest as you have heretofore suggested.

Rather the issue, so far as I am concerned, is that the people of kansas have the right to refuse to allow any part of their state to be made a dump for any garbage--not just radioactive nuclear garbage. Even you will agree that neither the AEC nor any other Federal agancy has the right or the authority to compel them to do othervise, no matter how vaidd it may make its reasons appear. What disturios me is AEC's effort in this instance to subvert that lack of authority by a "big-daddy-knows-best" campaign that is at best disingenuous.

It is on this premise that $I$, and other hansas officials, elected by kansas citizens to represent them, have a duty and responsibility to question the AEC, to ascertain facts for presentation to kansas people, and in the final analysis to carry out the wishes of those citizens, whether or not their views comport with AEC's desires or indeed even if those vievs may adversely affect the operation of privatelyowned giant power companies which operate nliclear plants.

It is now pertinent to recite a bit of history to prove my prior assertion that the AEC's research currently remains fragmentary and inconclusive, that it has not made requested Eacts available to me and to others and indeed has evaded responsive answers.

My initial inquiry to your agency on April 23, 1970, was a normal one asking for whatever facts were 
available in connection with the proposed lyons project. I had no preconceived notions that the AEC'S proposed fucility was good or bad, safe or dangarous. I knew less than nothing about atomic wastes. Iike all other Members of Congress who learn about potential Federal projects, I was properly curious and desired to know more.

AEC's initial answer the following day from your John Erlewine convinced me that it was important for kansas that I learn more. It was one of those "pat-re-on-the-hesc" type of buresucratic letters with wich many oE lis in congres ex ere a.1 too familiar. Mr. Erlewine sought to convince me that "extensive research anc testing" had been carried out, that the "facility vould oe safely isolated from fresh water aquifiers for geologic pericds of time," and "Offers" (Whatever that means) "efiective protection against accidental contact by man or animals." Need I interject hare that ten months later in your most recent letter you are not ouite so positive as your employee. You say that "if exploratory studies were to develoy objective data wich raise serious questions as to the suitability of the site for radioactive waste storage, the comission would cease work on the project."

I take this to mean that you and the $\lambda \equiv C$ still aren't convinced abolit tha permanent sazaty factor. Ny point is that we ate here dealing it th hunan lives,

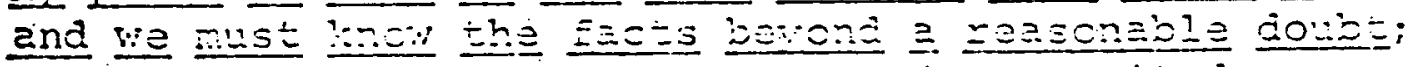
that a oreporderande oE the iacts just won't do.

Thus until and unless you are certain and the Kansas State Geological survey has no unanswered and unsatisfiea guestions, you cught rot to go ahead with the project itself. 
In the intervening 10 months since April of last year when I first sought to get some facts and further assurance fron the AEC, I have.written your agency seven times asking additional questions and clarifications of prior connents by you or your agents In the sane period I have received ten communications from the AEC including a meeting in my office with Mr. Erlewine.

On July 7, 1970, I received from Dr. Hambleton of the Kansas Geological survey an Interim Report on the storage of radioactive waste in salt at Lyons. Inis 15-page Rezort raised so many important questions

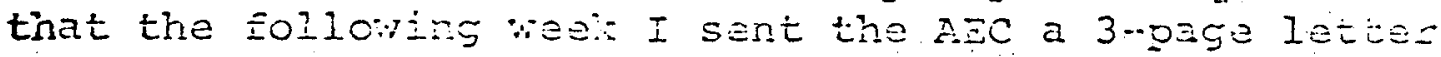
outlining in considerable detail the points raised by Dr. Hambleton, the aiscrapancies betrean his report and prior AEC connenses, and I requested a "Iibrary of accurate and incisputsble facts." Two wesks later in an effort to forestail further evasive responses, I sent you a l2-page letter specifically expressing my growing concern about the lack of reliabie facts and outlining specific questions such as the safety of the salt bea as a burial site, safety of transportation, comparison with other potential sites, what is the Federal Governent's responsibility to private power plants to dispose of their nuclear wastes, what is Kansas' responsibility to such private power plants, and requested further clarification of "the national interest" that would justify the dubious distinction of kansas being made tre national atomicwaste dum?.

Allow me to refresh your recollection on the AEC responses. First cine a 29-page report prepared by an oak Ridge stas meniber which analyzed the population of iyons and vicinity, its water and serage facilities, its geographic location, its transporta- 
tion facilities, the proximity of the salt beds. Even the AEC would harcily describe that as responsive. This was followed. by a six-page letter from you full of assurances but no reports or studies, formal or otherwise; then another letter telling me that safety studies are being conducted and that I will be kept informed of all significant developments; then still another letter saying that three fims have been selected to carry out the conceptual design work for the repository. In November of last year Mr. Erlewine forwarded the NAS Report, added that some core drilling had taken place, that the drilling aisclosed no geological problems, and that I would continue to be infomed of signj.zicrnt develozments and will be pronicid with results of studies and other docurents.

I have yet to see any of these stuaties or socuments. Most of the reports and stucies areingy? to me cane fron other sources, such as the Decenter 2 ,

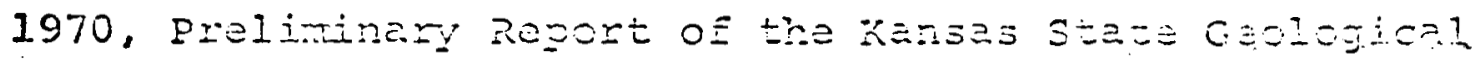
Survey, which was done uncer contract for the AEC. The final basic report by the state Geological survey now completed and ready for delivery to the AEC is not available to me and the concerned public. This is because, as you knor, AEC contracts require that public release be heid up for 90 cays or in scne cases no release. The report contains infomation that is inportant to rembers of the Kansas legislative assembly, to the Governor, and to all of lis concerned with the problem. I urge you to arrange for its prompt public release.

I am aware that this kansas Geological study is technically. limited to geological and hydrological problems. But I have little doubt that it will continue to raise questions dealing directly with thema? and radiation efiects jeczuse thoy impinge on lydzology 


\section{Dr. Glenn T: Seaborg}

March 1, 1971

and geology. They are the same questions raised in the December 2, 1970 , preliminary Report and remein unanswered by the jEC. We must conclude that AEC doesn't have the answers or that it is reluctant to reveal them - the reason I riised the issue of secrecy in my letter to Governor Docking and to which you now take umbrage.

on the geological and hydrological side, this Report wich none of us may see until you release it, cones up with a nen Eactor. The finding of a "sink" in the ricra formation suggests the cossibility, houever remote, teat njter could dvain throug the sait beas and carty radioactirity to the suriace. risis questicn can cnly be settied by further intensive study by the stata ceological surrey. I would hope that the AEC would connission further investigation by that body and postyone its request to go anead with actual site work.

In this connection, it is illuminating to read the NaS report of sovember, 1970, which Mr. Erlewine forwarad yth an inference that lils approves the lyors site as a cepository. The AEC has not yet satisfactorily answerea, nor has the A.EC dealt with, so far as I can determine, some of the questicns raised by the Comittee on Radioactive raste Management of the rational zcaiemy of Sciences in this Nas Report. Before rajioicgicai materials are comitted to the salt jeds, says tie Mas report, sereral problens shoula be resolves; viz., radiation danage to the salt, information on themal properties of salt beds and other key rosk units, subsicience of the mine, retrieval fians, transcortation problems, further geological evaluztion. Morsover, the Report notes that altiough the fiec ras already selected Lyons, many of 
Dr. Glenn I seajorg Nocin 1, is?1

its "recommendations are applicable to other sites that might be as suitable as the Lyons site." (Emphasis supplied).

The Interior Department's letter of February 3 , 1971, reports that "an endorsement of the repository cannot be given on the basis of the environmental statemenent or the included (NAS) report." I cannot be more emphatic myself.

If the AEC would spend funds on studies and surveys that will produce generally acceptable facts that the wastes can be neutralized in some fashion, made safe for transportation and handling, retrieval carried out by genexa?ly acceptadie known methosis-ninen

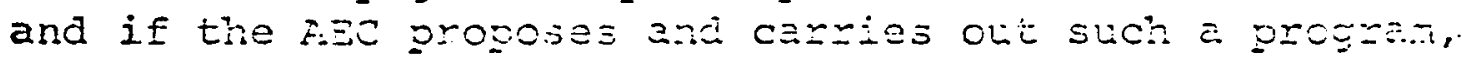
it will have the support of all concerned persons, in and out of kensas.

It will then be time to deteruine were such

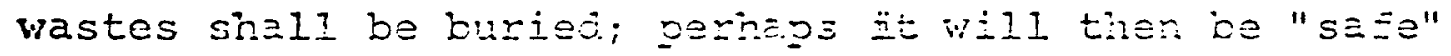
to bury then inmeilitedy ajjacent to the porer plant. that produces tinen. It is obviously not safe to do that now.

Under these circunstances AEC should not put the cart before the horse by croposing actual site work be done while it carries out adiitional research to determine if what it has begun will be safe later on.

I, for one, simply don't trust the AEC to get authority fron congress to begin work on the site anc accept its assurances that it. MII stop work sone time in

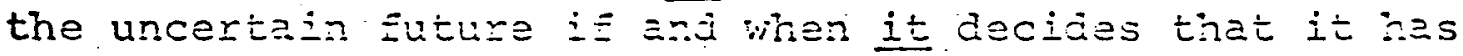
a safe method of handling highiy radioactive wastes that will remain dangerous for a half-million years.

This letter has jeccme overly long, Dr. Seaborg, but I simply cannot let pass you reference to "errors" in my lette: to Governor Dockirg. Its an old debatoz's trick to pick up a minor Elay in an arglinent in an $E \equiv-$

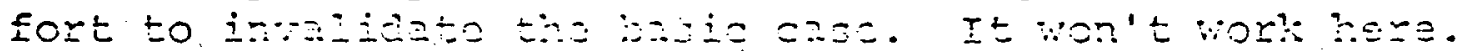


You say the salt does not "melt." Not being a chemist, obviously I did not use the term in its chenical sense. You state that the salt wili become a plastic seal. To the layman the difference is meaningless, unless you are prepared to argue that when encased in the plastic the racioactivity is less dangerous than if the salt had been melted and its crystalline form had undergone change. I simply sought to question if the salt seal, whether it came about through plastic flch or "melt", would effectively retain radioactivity and prevent its subsequent escape. In any case, you dia not answer the question.

Your letter again deals with retrjeval. My point here was that like Mr. Enlewine months aso, you emphasize in one place that the wastes are to renain in place gemarentiy. But in another place you derote a page to repeating your response to the richita Eagle which wanted to knoil wat could be done if danger threatened after burial. You could have brushed the danger possibility aside, as Mr. Erlevine did, or relied on your own stateneni that permenent means cemanent and retrieval is not contempiated. But tha fact that you dealt with the retrieval projlen certainly infers to a reasonable man that it is indeed possible that the wastes nay have to be dug up sometine during the half million years when they are dangerous. The AEC's posture suggests that the retrieval problem hasn't been researched in ang grazt depth, since you explain that "concepts" for develoging retrieval machinez design of the facility. Wh not design and test suci machinery before you build the facility?

Incidentally, Dr. Weyer raises the problem of locating tine. stored tubes of radioactive material a.ter their containers have corrcied and they have "movea" through the salt becis. I supgose one ansirer is that some future ganenutions couid o: excavate milions o tons ó dangerously radioactive salt,

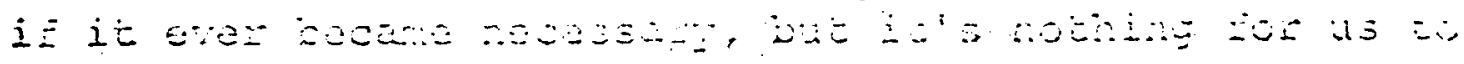

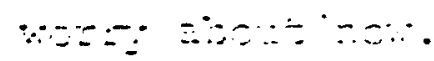


I am well aware that the 80-million gallons of wastes referred to in my letter are AEC wastes and that the initial and primary purpose of the lyons facility is linited to private power plant wastes, totaling now about a half-million gallons. Nevertheless. your attachment ouickly modifies the linitation by explicitly stating that Ivors would de a back-uo

storage facility for your neC wastes if vou can't find a more suitable means of handing them. The fact that AEC is "not glanning" to ship its wastes initially to Iyons does not, in my judgnent, varrant. a deriai that fEC will not so do, particularly wren you introduce a caveat that you may. Some crajence also must ba given AEC intent to eventually expand the site by Mr. Erlewine's earlier comment that "ajcut 2,000 acres" would be required. This has now best modizied in your letter to "less than 1,200 acres o land surjace and additional unierorond rictes." Coviously this means the rights to a subsential screase surcounding the 1200 acre site. Does the AEC sigggest that the surfice area of the "adiltional underground rigites" will be usable and habitable in the nomal sense; i.e., wells can be drilled, livestock raised, humans live in safety and comfort?

Your letter brusines off the problem of transportation sajety with a recetition of earlier statements that a nazard analysis report must be prepared You add that since nuciear-power plents and Euelprocessing plants are being constructed and planned, it is imoerative that there be safe metnods of trans. port for highly radioactive materials. Such methods do exist, you conciude, and AEC has a long and excel. lent record of safe shipments.

My information is that the record isn't all that excellent. More importantly, wat are these 
methods of transport; why aren't we told about them in some informative detail so that others experienced in transport matters would be able to evaluate them. Congress involved itself in nuclear-accident problems, as you know, tinrough the price-Anderson Act of 1957 by setting damage limitations on private insurance and government liability. The fact that the legislation was enacted confirms congressional acknowledgement that a nuclear accident is possible, including transport. Kansas would becone the place to which all radio-active wastes would be sinived, a fact that substantially insreases the opportinity for nuclear acciaents.

In my juagmente, Dr. Sejborg, the Aac case just won't hola vater; it's full of the kind of burea:cratic assurances thet I have in my long experienge in Washington cone to mistrust. The Interior Department's comments on the AaC's dratt environmental stetsment fortifies my sussicions. kansas' citizens will read it with great concern. The AEC may then begin to realize that we are not country bumpkins who can be taken for granted.

I enclose copies of three of a number of kansas nevspaper editorials from all orer the state expressing public opirion of tha AEC's radioactive-waste durp. They may convince you that the place to experinent in finding ways to handle radioactive wastes safely is in the laboratory and not in Lyons, Kansas.

Also attached are extracts from four reports that appear neaningful to me. I knon you alrejdy nave the full texts.

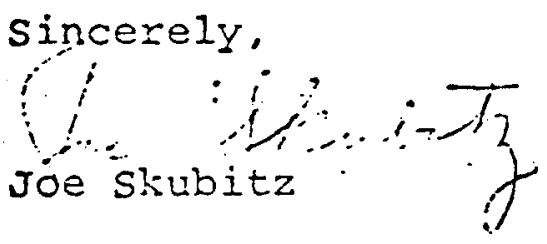

Dr. Glenn T. Sezborg, Chaiman

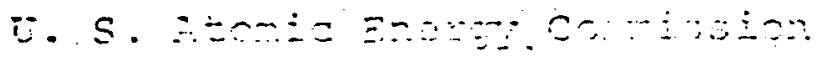

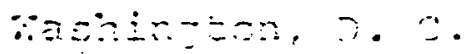


Dr. Glenn T. Seaborg

March 1, 1971

Copies to: Eon. Robert B. Docking

Each individual Member of the Kansas

state Legislature

Hon. Robert J. Dole

Hon. James B. Pearsion

Hon. Garner Shriver

Hon. Larry Winn, Jr.

Hon. Keith Sebelius

Hon. William Roy

Each individual Mamber of the voint Conmittee on Atomic En:ery

Dr. William B. Hambleton, Director

Kansas Geological survey 
"PRELIUIAARI REPORT ON STUDIES OE THE RADIOACTIVE WASTE DISPOSAL SITE AT LYONS, RANSAS

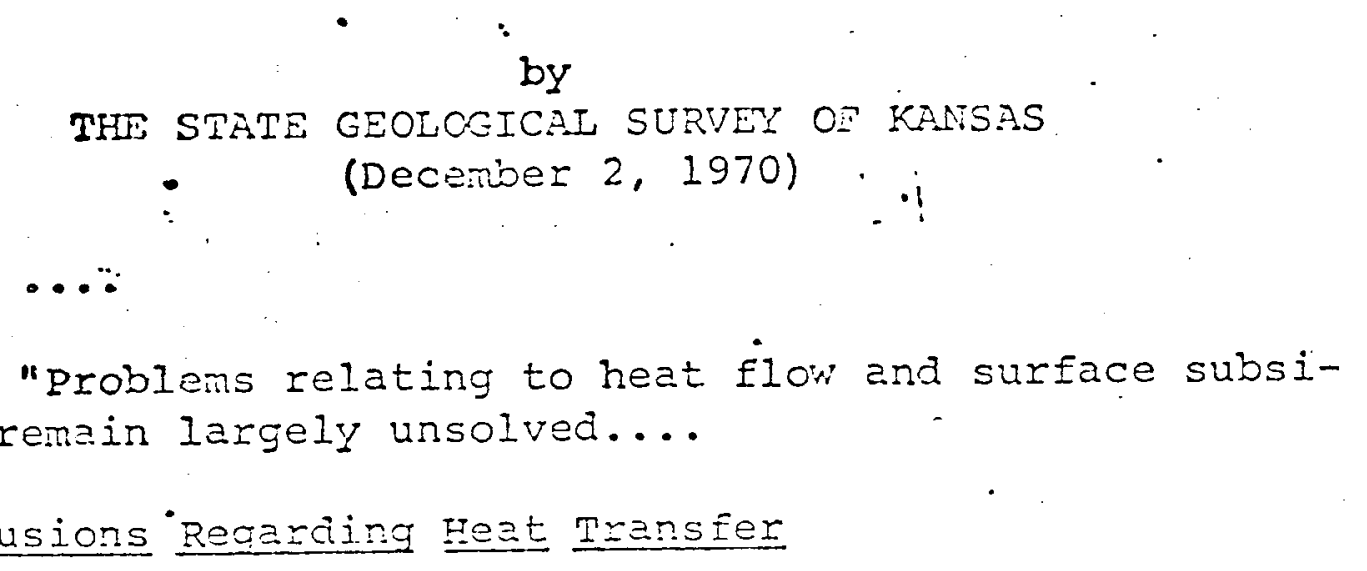

"Oak Ridge National Iaboratory and A.E.C. staff have exnibited remarkaly little interest in the heat

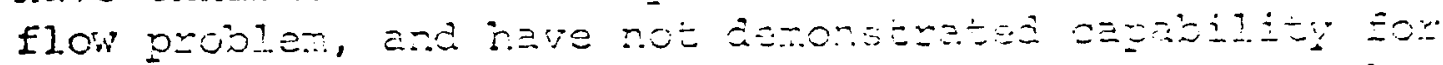
solvirg threa-ainensicul problen involving a conlex laninated section. The interattion of subsicience, thermal expansion, and heat tow could be responsiole for breaking the seal of orerlying rocks, and paritting entry of surzace or subsur logical survey regards solution oz this problem as crucial to the sarety of the repository site.

"... A problem arises from the potential capacity of the salt to undergo rapid thernal excursion through sudjen release of the stored energy. The release of 80 calories per gram rould cause tomperatures in the affected region to rise fron 300 degress C. to 520 degrees $c$. These high temperatures could result in greater flowage of salt around the containers, and could cause an explosive affect due to this sudien themel sxpansion. As long as the waste containers maintain their integrity, only very small guantities cif salt mo:ld be subject to high enezg, heavy particle radiation. Horraver, release. might occur once of trice a year for about three years and melting or explosicn night cause containers to migrate to loiver ceptis, possibly to shale layers, and faults could develop in-overlying rocis because of explosions.

"In dadition, the netal containers are expected

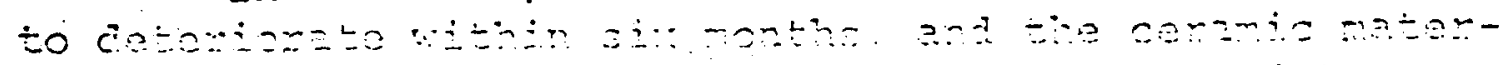

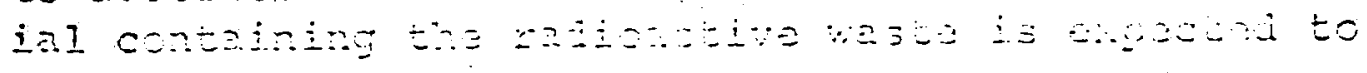


deteriorate within several years. Accordingly, racioactive particles could migrate through the salt. If the particles are heavy, downward migration might cccur due to localized melting; if they are light they mignt migrate upward. water is available in the salt, ard the waste particles could be suspended by turbulent boiling. Furthermore, the solid particles would expose the salt to significantly higher radiation doses. Although the total expected dose per container is $2 \mathrm{x}$ $10^{10}$ rads, we have indication that the dose may be significantly larger.

"The ceramic silica glasis also can store energy, and gamna radiation can cause chenical breakajonn of salt. Radiolysis could result in formation of new chlorine compounds that are capable of leaching plitonium.

"Conclusions Recardina Radiation Damage

"Staff of oak Ridge rational Laboratory and the Atomic Energy Conmission have exhibited renazkably lit:la interest in studies of radiaticn ciamage. The state ceological surrey ragarus this problen as oxtrene cy critical to safe storage of racilozctive waste at the Iyons sita.

"Transportation and Retrievai of Waste

"Although the State Geological survey has no direct responsibility jor transportation proplems an: retrieval of radioactive vastes, we woula be reniss if we did not' call attention to these critical Esctors and reinforce the conclusions and concern of other state agencies involved in tisse groblems. Tie judge that

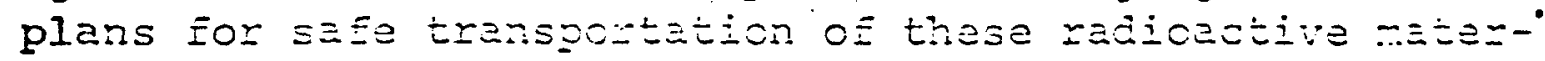
ials are completely inciecuate and that no conting:-:oy plans for retrieval of vaste exists at all. We concilisa that these two elements are critical and crucial to the safe storage of radioactive materials at the Lyons site." 
An Associated press article quoting R. E. Tomlinson, Manager of Research and Dorelopment

at the Hanford Atonic Works,

with respect to dangers of transport of atonic wastes.

"PORTILAND, ore. (AP) -- A research executive for some facilities at the Hanford Atomic Works said Tuesajy; in discussing disposal of nuclear wastes, 'I don't like the thought of subjecting people to the possible hazara of radioactive salts all the way from here to kansas by truck or rail.'

"R. E. Tonlinson, manager of research and derelopment for the Atlantic Richfield Fanford Comoany, said compeny encineers aro stubying the possibility of dixiling

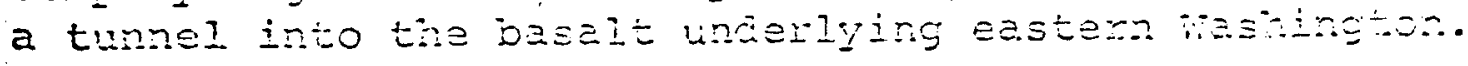

"wastes have been accumulating in underground storage at Zanfond For 25 years, he said, and are so yjst that to nove the high-ievei solids to the lyons rezosizon: woula take a string of trucks spaced 10 minutes aż=t, moving continunusly at 60 miles an hour for five years to complete the job.

"'I don't like the odds,' he said.

"Tonlinson said the suggested tunnel vould rave to be 20 feet in dianeter and 17 miles long to handie jast accumulations and future wastes in vasnington.

"If preliminary studies are favorable, he said, "we will be reacy to sink an experimentel shajt and $\dot{a}$ ig a. cavern about 1973 of $1980 . '$ The tunnel would be at.

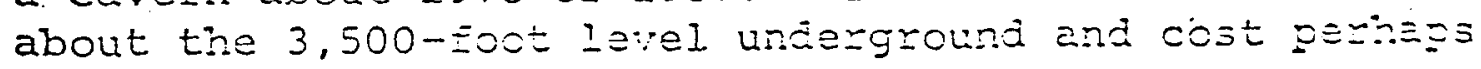
$\$ 5$ bilition, he said." 


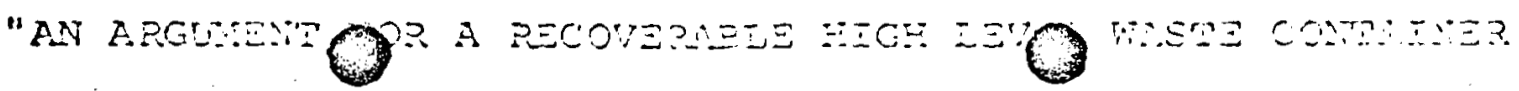

Walter Heyer

Professor Nuclear Engincering

kansas state university

Maniattan, Kansas 65502

"This zeport has been initiated ard prepared by the Department of Nuclear Engineering of kansas state University as a service to the Governor of the state of Kansas and the Kansas Nuclear Energy council. It does not represent a portion of any existing project supported by any outside funding group or agency.

\author{
"Curtis G. Chezen

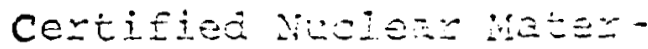 \\ ials renses: \\ Kansas inclear Enazery \\ council \\ (Decerber 3, 1970)
}

"The basic concept underlying the perpetual storage of high ievel radioactive westes (resulting from the reprocessing of burned nuclean poived, electric generator fuels) in the proposed vitional ruclest iaste Repository at Lyons, kansas is the inviolability of the salt bed that will act as the ultimate storage container for the wastes....

"However, three questions exist regarding the long term stability of the salt bed in the Lyons vicinity. All of thes equestions are reported to involve problens of water invision oz the storage site...

"... However esthruates do cocur in all areas of the unitea states to scre extent. If a combination of events snould occur that pould pernit (1) water to invade the high level waste storage site and (2) provide an exit Eor the radioactive waste contaminated

- hater to escape Eron the salt, obviously a very hazara- ous situation vouid exist. once presence or the inninent presonce os vator in tive sito were roted, the prudont action rould be to remore the high lovel waste to a more 
Dr. Walter yer

stable storage site.

"It is expected that all efforts will be made by . AEC to insure that the site selected for high level waste storage will be safe within reasonable limits. However, in the concerned public's riew and in reality, the chance situation will still exist that would permit radioactive contamination to leak from the site to the biosphere unless the high level radicactive waste material is removed. Thus high level wastes should be stored in a manner that will permit their removal with alacrity and at reasonable cost. It is expected that much public concern with the proposed storage site would be relieved. if a concept of recoverable storage was adopted.

"... If at sone future time it is prudent to remove the high level vastes from a particular storage site, the drums could be located and removed in a reasonable time and at a mucin lower cost than would be recruired to remove waste fron a corrosion ruptured or aisintegrated waste canistex. It shoula be noted that it may be very cifficult atter long storage gericds to loceta with certainty a singie canister buried directly in the salt. It can be expected that at the 200 degree $c$ tenperature surrounding a stored waste canister, a canister may migrate both down into the salt and laterally through the bed with time. Using the concrete drum container concept, migration rates will be considerably retarded and in any case locating a lazga drun wolild be consicerably simpler than locating a four or six inch dianeter slug of unshielded high level solidisied waste. ..." 
"UNITED STATES DEPARTIEST OF THE INTERIOR

Office of the secretary

Washington, D. C. 20240

February 3, 1971

"Dear Mr. Erlewine:

"This is in response to your letter of November 30, 1970, requesting our comments on the draft environmental statement on the Ftcmic Energy Comission's proposed radioactive-raste repository near Lyons, Kansas.

"... Our concerns are based partly on the statements in the draft environmental statement (p..18) that, although retrieval of tha wastes is conceptually possille, tha emplacement of the wastes in the sait formation at iyons would, actually, be recarded as 'permanant storage'. such a permanent comitment of the wastes reguires a very strong and scientifically convincing demonstuation that the wastes will renain in a geologic undisturbed and hycrologicaliy isoleted position zon the several thousand years required jor the decay oj the high-level fuel-reprocessing wistes, and the several hundred thousand years renuirea for the decay of the other 'alpha-omitting' solid wastes (winich contain longlived isotcpes such as pIutonius). Such a scientific and engineering denonstration coes not appear to be impossible at all, but it vill require a more thoroligh and better-docunented approach than is presented in the draft environnental statement.

"Although the subject environmental statement indicetes in sumery (D. 2) that no significant impact on the environnent is anticipeted Eron the construction or oper. ation of the repository, it coes not present sufficient information to evaluzte the potential impact of all aspects of the facility. Therefore, an encorsenent of the establisiment of the repository cannot be given on the basis $a$ is the envirchinental statament, or the included report by the NAS-NRC Comitte=. The NAS-NPo Committee, of course, has given criy a gializied endonsenent ( has pointer out (p. 7-9) special nanagenent problems; and

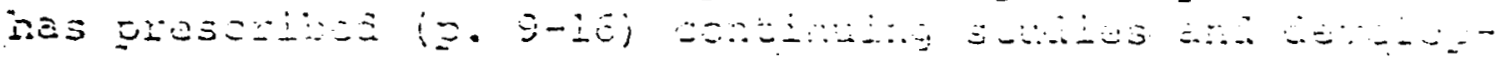

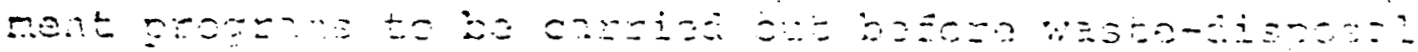


Departmengifo the Interior.

operations begin. Most of these problems and investigations have a strong bearing on final decisions as to whether the project is feasible.

"We believe that there are inadequacies in the presentation of specific items in the draft statenent that the commission may wish to consider in preparing its final statenent. ...

"A brief analysis of earthquake hazards is presented on pages 24-27 of the draft environmental statement. Nevertheless, since earthouakes' have occurred at many places in the kansas-iebraska region, they can be expected to occur in the future. Therefore, the statement should derive and specify the expectod eartinculs; the expected vibiational or other ground eEsacts at the site; and a definition of the potential hazard to mines or surface structures. . .

"... Nevertheless, in view of the above-stated concen related to the lack oz data on the 'high-ievel.. $e^{\prime}$, it should be pointed cut that further analysas cf thetral and other stresses on the heterogeneous rocis in the Hutchinson Salt Member at the site are warrentsi. Thesa stresses (prolonged heating and exposure to radiation, and subsicience and dejornation associated with the mining and flow of salt) could result in fracturing of the rocks above the salt. If the system of irduced iracturas extends upvizd through the 500-foot-thick section of shales between the Hutchinson salt and the stone corral dolomite, which is a frash-water aquifer, ground water might move down to the salt. ... In vien of the fact that the 'nigh-1avel' and 'alpha-emitting' wastes will not have deceyed to innocous levels of activity for thousands of years (in the case cE plutoniun, hundreds of thousands. of years), there would bo adequate time for this circulation systen to transport radicactive vastes to shallow aquifers or to the surface. These problens are not overwhelming, but they are legitimate areas for further anal$y$ sis and documentation. ...

"The following design critaria, operational procedures,

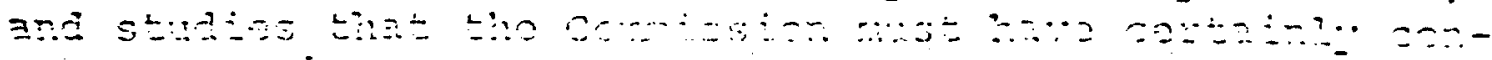




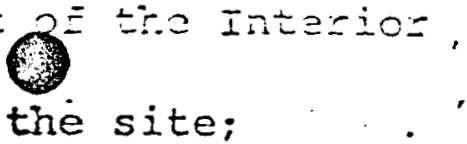

9. Provisions for strategically located mine safety areas and/or sinelters to wich personnel could retreat in the event of a caving or radiation accident, and from which they can be rescued without bringing adioactive contarinents to the surface;

"10. Provisions for installing radiation monitoring equipment and/or sealing of all existing oil, gas, and water wells within or surrounding the repository site;

"11. planned means for cleaning up radioctive waste spillage within the mine, receiving facilities, and along principal access roules.

\section{n...}

"A problen area that is still lnaer investigation by the Connitiee on Radiosctive raste yanegenent is the disposal of salt excavited fron the repository. Since this could affect the vater quality oi surzace or ground-rater in the site vicinity if incorrectly conducted, further mention should be included in the statement.

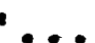

"sincerely yours,

"(Sgd) Hollis H. Dole

"Secretany of the Interior" 
THE FARSONS SUN

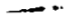

$\ldots$

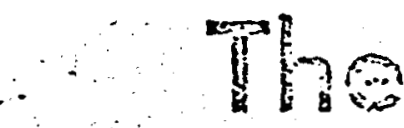

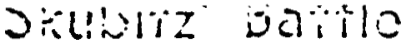

- .ue to the traditions of his native Känsas Ealizaus. Een. Ina Skubiez has fnuglt many scrats in his time, het noile may be as important as one which finds him ruining biaw: on the Atumic Energy Commissinn.

The AEC proposes to dump the nation's atomis vastes into an oid salt mine near lyons, in cenlral kansas, and Shubitz has luened into the leating congressional critic of the flan althougl! tite site is not in his district.

- Scientisis arc uneasy about tile scheme. They say the AEC has given it on?s cursory siudy and does not know or camer furetell the ultimate consequences of storing live radiosctive nialerial undarero'nd-particular. ly since the wastes wil remain "alive" for the next $3(3,(i)$ years.

While Gov. Robcrt Doclians conccivably still ceuld be in office by the end of that timis, the sinte GOP having iailed to recoup antd rescoub, fo:" of tha rest of us will ba cround, alive and kichilig. Slibubitz is engaged in a moniatmental struente, botil foi the prezen: and counlless future scicraticns.

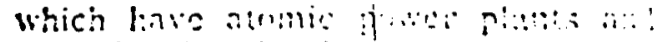

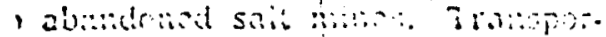
1. . Ion of the hinhly hezacions y ials could be climinated if mincs closer to the souterce were tetilized

but the AJ:C doesn't uant to des that. It chooses instead the Lyuns mine, pes. sumably becaluse the poptiation hereabculs is much thinner and fewer pe:sons will be subject to ristis if tia whole fantastic project llere tn blow un oa:c day. Kansans neverllaless putis a hich value on human life, even it :t? state laclis the concentration of it tha: cxists clsewhere.

If it hasn't tumbled yet to the fact. the fotomic Energy Commission wi: find trat it is tangling witis at buzzant. in Shubitz. Once he hi:j cirosen his tarect and his ammunition. Skibitz is. a hurd man to dissuale or deicat.

In challenging a hillerto sacred co: amons federal burcans and incisci 0 : Anerican life in gencral. Stoubiz no: only is wagitls a batelo io! Mansas but. probably for the whole raticn. itc is questioning dubious promises nen which tire $A E C$ lias staked momentous gam. bles it:at extcrad far beyond Lyun's' modest municipal limiis.
Congressmain Jos Skubitz spant nine menils rescatrehing the ciucstions arising froni the Aumic Encrey Commisnion's plan to sturc alonic Wastes neat Lyons.

The furtines he dus, the more convinced Joc becene that Sansus was designated an atomic dimp not bocause it yould ive sale, brit rathar because it would ba the casiest 1 a $\%$ vut. If the AlEC tried to store the wastes ncar populiated arcas, people would object. So ship it to the bumptins in Kansas.

Thuntis to our Coneressman. the plan miny be bioclict. At lcast until . it is proven saie beyoutd all reisstaable coubt.

When you constrior that Lyons is not wibita bis district, it sacens a::

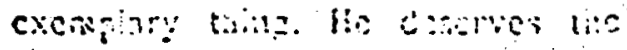

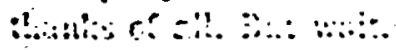

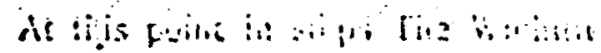

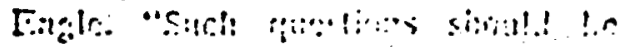

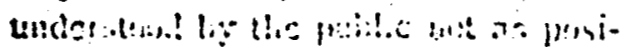

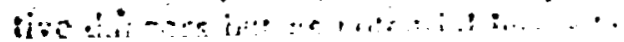

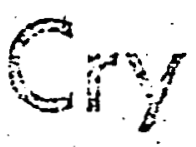

postulated by acolunists whos duly it is to insegine every possibie thing that coutd rerong. It would unly hindar the search for answers ii every lian. san g.ot as hystorical as l:as Rep. Jos Skubitz of P'ittsucurs wiro represents soutlicust Kansas not the central area in which Lyons is locaisd."

liaybe nine months of research strilies the high-ilying Engla as hysterics. bet uhers sibuld see it as re. sponsible inquitry.

And since when are atomic wastes not position dangors? If The Earle writers ;ijolulate that they are soma. thing les. they might stump to locatc the dirisp in Wiçhita.

As for telling Shubitt to minel his

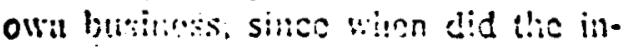
terests of lainsints change at tha

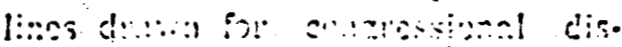

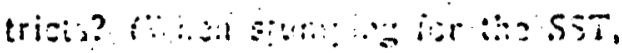

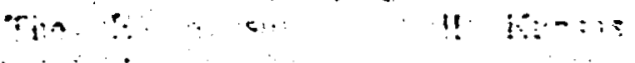

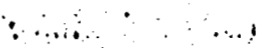

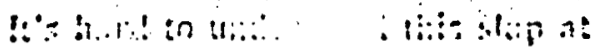

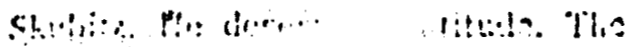

Pg. 2 The Chanuic T:: Editorici-

February 22, 19; 
February 22, 1971

\section{Editorials}
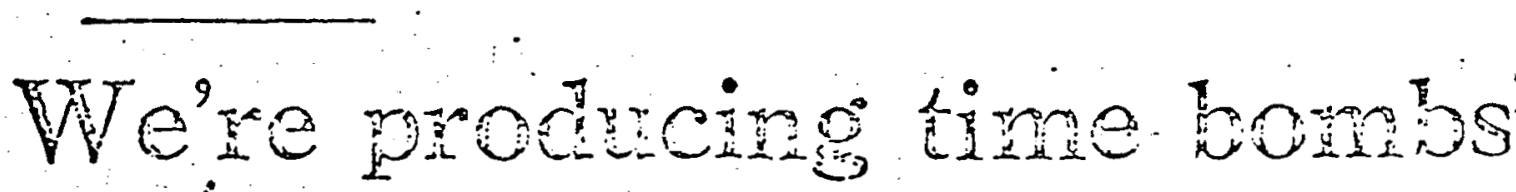

Speakins of the posposal to dinep radio. active waste in the sillbels neor Lyons, the Wichita Fagle said Sunday:

"... It would only hincer the search for answers if ercly hansun got as hesterical

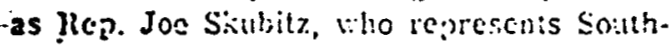
casi sousas, tot the cerrial area in : :hich Lyons is locaicd.

"Sk:ubitz has demanted that the gore:nor, without ftrther qussion, opyose the installation as making fansas an alomic sarbage dumin.' That's cattehy, but ctintuible phrases aien't what is needed to dicicic lhis scrious maitie:

"What is neeled is a full sot al arcuars fron the Alomic Fue:".: Conneissimn. Ans they should be made public as soon as tiae state riccives thin."

Joe Sribit\% nidele his argument acainst

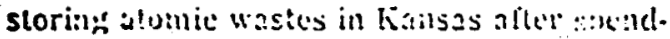
ins nine nesuths tryint to sel the Al:C to

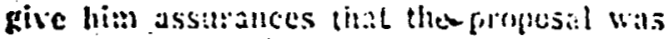
albsolutely saic.

This hardly qualifics is a: "bysterical" decision.

The Stale Goolnical Sintey repont cat the

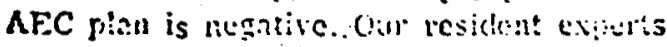

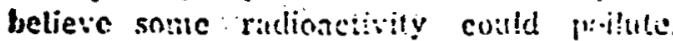

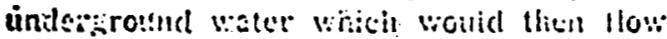

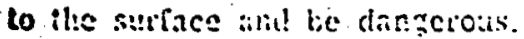

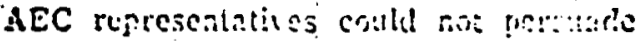

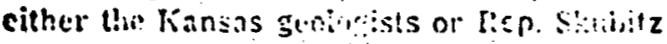

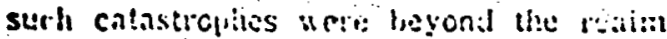
of pussibility.

: Scicutists toll us the ::aste's w!ich wom!lis

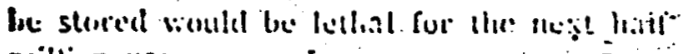
nilliun sears.
It is titerly incredible that any sane indivirlual would uncertoke to guarante: inat nothing could happen within jitu. Uh years that might not release this deadly substance from its storcholise.

If the material can be put underground by man, then other men 20 gencrations from now - a mere con sears - could dig into it scarching lo: minces!s or building an underaround city against some unknown threat and dic, victims to o:ll callousniss.

Is lecons and that area forricl suic

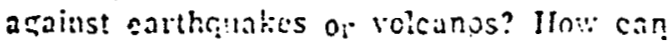
anyone be cortain? And isn't certaing reguired when we are tallii:! sljout a li:::th of time many times grcater than the tr:al span of civi!lzatirsi to cis!c?

Our respousihitity for the atumic wastes we are genernting lasis as long as the ma. teriel is cicadiy. not just for the fliture ․:

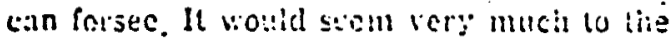
proint :o start a crash prostran on visys 10 ricfuse these bambs helue we bury tiem.

At the vers least, it woukl only swem pricient io insist i!lat no wastes dé probltced which-w:oud remsin leihal lonrer than like geteratien which prolloces then ean be eer. tain thit theit location sate the nutu!e of the threat ther pose wctid remian known.

- We have no way of trowisig that such information cad ie puesorved for more ! :an a voug fe:" Ec:icraitions.

Fap from heing hysicrica!, Joe Strit.itz. anpers 10 bo olle of til: fe\% in a pos tisal

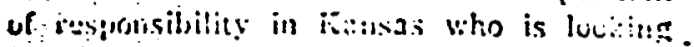

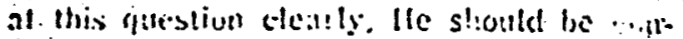

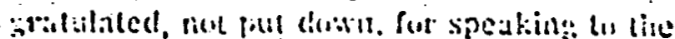
issuc. 


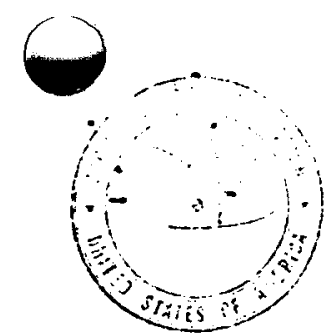

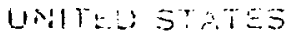

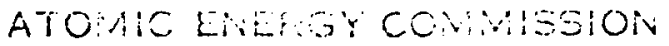 \\ WASHINGTON. DC. 20545
}

FEB $\quad 2 \quad 3 \quad 1971$

Honorable Joe Skubitz

House of Representatives

Dear Mr. Skubitz:

My fellow Commissioners and I wish to comment on your letter of February 12, 1971, to Governor Docking, a copy of which you sent to me, in which you seek support in opposing the proposed salt mine repository for solid radioactive wastes near Lyons, Kansas. We regret that you do not support the project, particularly in view of the extensj.ve exchange of correspondence between you and the Atomic Energy Commission since April of 1970. In this correspondence, the AEC has attempted. to ansiver forthrigitly each question you have raised and to provide all information which you have requested. We also note that your letter to Governor Docking contairs errors regarding the project. These are noted in the attachment to this letter.

We cannot agree with the assertion that AEC studies concerning this project have "been kept a deep dark secret." There has been no secrecy about this project. The general public, as well as the officials of Kansas, have been given extensive information on all aspects of the project. The Kansas State Geological Stirvey and other Kansas governmental organizations have been briefed at length and have access to all the extensive technical information on the project. They are also helping AEC to carry out many of the on-going studies regarding the proposed project.

Certainly there has been nothing secretive concerning AEC's intent to request Congressional authorization. For the project in the $F Y$ 1972 budget. This was announced in an AEC news release of June 17, 1970, a copy of which was sent to you. This intent has been repeated many times publicly since that release.

Your letter states your satisfaction with the growth of nuclear power throughout the United States even though Kansas does not yet have plans for a nuclear power plant. However, it is important to understand that the growth of this badly needed source of electric energy cannot proceed for long without provision for safe means of storing the radioactive wastes which result from the reprocessing of nuclear fuel elements that provide the energy for nuclear power plants. 
You have asked why the AEC has selected Kansas for this project. The area was recommended to $A E C$ by an advisory comittee of the Academy of Sciences in 1955 and, as you are aware, another Academy comittee confirned its opinion of the suitability of the storage concept and suitability of the site in a report issued in November 1970. Extensive research and development work has been performed in the Carey Salt Mine at Lyons, Kansas since 1965. We know of no other more suitable site, although, as we have stated, other geologic fornations in other areas of the country may also prove to be satisfactory for such repositories. We believe the project is in the public interest and we do not believe the project represents a threat to the safety of the citizeus of kansas.

In conclusion, I reiterate what AEC officials have repeatediy stated publiçly. No radioactive waste will be placed in the Lyons salt formation until all the necessary studies and safety analyses have been concluded and the comission is satisfied that it is safe. As we proceed, if exploratory studies were to develop objective data which raise serious questions as to the suitability of the site for radioactive vaste storage, the Commission would cease work on the project. To date, we have no reason to believe that this important project should not proceed if authorized.

If we can provide additional information concerning the project, we would be happy to do so.

Cordially,

/s/ Glenn T. Seaborg

Chairman

Enclosure:

Comments re 1 tr

cc: Honorable Pobert B. Docking

Honorable John O. Pastore, JCAE

Dr. Willian B. Hambleton, Director, KGS

Honorable Robert $J$. Dole

- Honorable James B. Pearion

Honorable Garner Shriver

Honorable Larry Winn, Jr.

Honorable keith Sebelius

Honorable $\because$ illian Roy 


\begin{tabular}{l} 
Comments re Congressman S'ivisitz' Lettar \\
To Governor Docking dated February 12,1971 \\
\hline
\end{tabular}

1. Allegation that AEC intends to ship 80 million gallons "radioactive soup" into iansas.

Only solid wastes would be stored in the proposed facility and solidification of liquid wastes would take place before shipment to the facility.

The "80 million gallons" apparently refers to high-level liquid wastes now stored at A.C installations and not to wastes from commercial power plants because currently there are less than 500,000 gallons of commercial high-level wastes in existence. AEC is not planning to ship high-level wastes from AEC installations to the proposed Iyons repository; however, it would constitute a possible backup storage facility for these AIC wastes in the event other storage methods now under study prove not to be feasible. The Lyons facility would be primarily for high-level solid radioactive wastes from commercial plants.

The allegation that "AEC is frantically seeking a permanent burial site (for AEC wastes) because the containers are deteriorating rapidly" is not correct. As Mr. Skubitz was informed by letter of June 30,1970 , AEC has not proposed to construct the proposed waste repository anywhere but Lyons, Kansas, and AEC has not been turned down by any State as Mr. Skubitz' letter would indicate.

2. Extent of land involved.

Mr. Skubitz' letter states that AIC plans to buy "2,000 acres" of land. Actually AEC intends to purchase less than 1,200 acres of 
land surface plus some additional underground rights. The waste storage rooms would be located entirely under the surface acreage at a depth of about 1,000 fect.

\section{Container Deterioration.}

Although the high-level solid wastes will be in metal cans,

- it is the salt itself that will constitute the primary containment for the wastes. Under the earth pressures at a depth of 1,000 feet plus the themal effects of the wastes, the plastic salt will close about the vaste containers and effectively seal them in place. The salt does not "melt" because the heat from the wastes will be far below the melting point of salt. It is intended that these wastes, once emplaced will remain there permanently. Thus the desirability of increasing container life expectancy is a matter related principally to operating requirements rather than a matter affecting the suitability of the concept itself.

4. Economic Benefits of the Project.

AEC has never sought to sell this project on the basis of economic benefits to the community. We have attempted to respond to questions concerning the number of jobs to be involved, etc.

With regard to use of the site as an industrial park, as has been proposed by local interest in the community, AEC has indicated its willingness to cooperate if the State or community wishes to propose such a use. With regard to heat at the surface, calculations show no discernible temperature rise for many years. In 
fact, it would be 800 years before the temperature vould rise $1^{\circ} \mathrm{F}$, which should have no effect on uses that can be made of the surface area.

5. Retrieval of Waste.

We are including in full the question and answer which was provided to the Vichita Eagle on the subject of retrieval of waste. Q. "Is any specialized equipment currently available or being designed which could simplify removal of the buried radioactive waste from the mine, should it become necessary due to emergency or other reason? Will such equipment be available and stored on site when the Repository operation begins?"

A. "Once radioactive vastes are emplaced in the salt repository, they will be regarded as in permanent storage. It is not planned that they will be relocated elsewhere. Retrieval would only be considered in light of an objective safety problem under circumstances which to date have not been postulated. However, the facility will be designed so as not to preclude retrieval. Further, the burial locations for each container will be accurately surveyed and recorded so that the precise location of the wastes will be known. Retrieval through use of remotely controlled automatic mining equipment would thus be possible. Concepts for retrieving the stored wastes will be examined in the course of the design of the facility. 
"It is our opinion that the technology is available which vould permit retrieval of the radioactive waste if absolutely necessary. The question of whether or not equipment should be developed, built and stored on site will be evaluated during the design."

The foregoing statement by $\mathrm{Dr}$. Seaborg, does not admit to the inherent danger of the burial plan. To the contrary, it confirms our belicf that prior to emplacement of any waste, sufficient data will be available to confirm the long-term stability of the site.

6. Transportation.

In letter of April 24, May 11, June 30 and August 8, 1970, from AEC to Mr. Skubitz, the subject of the transportation of radioactive waste was discussed. These letters pointed out that:

"AEC procedures require the preparation of a hazard analysis report for projects such as this. The procedure applies to transportation methods as well as facilities. AEC has consistently taken the position that in the transport of radioactive materials, they must be so packaged and transported as to assure that if involved in an accident the wastes will not be released to contribute to the consequences of the accident. This approach will govern the transport of the radioactive wastes to the repository.

"Since nuclear power plants and fuel reprocessing plants are being constructed or planned in many areas of the United 
States, it is imperative that there be safe methods of transport for highly radioactive materials. Such methods do exist and $\mathrm{AEC}$ has a long and excellent record of experience of safe shipments.

"Any initial waste repository, wherever located in the United States, will require shipments of wastes to it from varying distances and through many states. It is not feasible to propose simultaneous construction of several repositories in different areas. Even if one vere to attempt it, much time would be required to identify specific locations that might possibly offer geologic conditions that would be equivalent to the Lyons site. More time would be required to acquire firm geologic data equivalent to that known about the Lyons site."

7. Vital service to the Nation.

The fact that there are no nuclear plants in Kansas and that the present nuclear plants are located principally on the Eastern seaboard fails to recognize that in the projected growth of the nuclear power industry, plants that are now under construction or being planned will cover most of the states of the United States. As we have indicated previously, the viability of this industry Is dependent in part on the ability to handle the radioactive : waste generated in the nuclear fuel cycle. Even its critics have recognized nuclear energy as being important to resolving the 
energy crisis facing the Nation today. Mr. 'Slubitz' letter mentioned the fact that this facility would be tax exempt; hovever, in AEC's letter of July 31, 1970, Mr. Skubitz was informed that the AEC has authority to make payments in licu of taxes to taxing authorities resulting from a tax loss as a result of Federal ownership.

8. Allegation that the Commission is uncertain of the safety of its procedures for burying waste.

In selecting the Lyons site, the Comission stated that this was a tentative decision and was, from the beginning, subject to confirmatory geologic and hydrologic studies. Additional geologic studies which have been planned by AEC incorporating recomendations of the NAS Comittee and others, including the Kansas Geological Survey, are being carried out. These confirmatory studies are not indicative of uncertainty on the AEC's part regarding safety, but are to develop as complete an understanding of the geology and hydrology as is possible to preclude any safety problems. As noted in AEC's letter to Mr. Skubitz of August 8, 1970, the Commission has no intention of burying wastes in this facility until all the pertinent data is available to support the safety of this operation. However, nothing that has been developed, to date, Indicates that the site would not be suitable.

9. Allegation that the development of this facility is for the : convenience of privately omed utilities seeking a cheap means of disposing of vastes.

As noted in $\mathrm{AEC}^{\prime}$ 's letter to Mr. Skubitz of June 30, 1970, this facility will be operated by the Federal Government on a full-cost 
recovery basis, including recovery of capital costs, and vill in: no way be subsidized by the Federal Government. Under the requirements of the recently adopted amendment to 10 CFR 50, comercial fuel reprocessors will be required to solidify their high-level waste and transfer such wastes to a Federal repository. This action, taken in the interest of public health and safety, will most likely increase rather than decrease waste management costs. Thus, the Comnission in proposing to establish the Lyons, Kansas waste repository is emphasizing safety and not cost. 


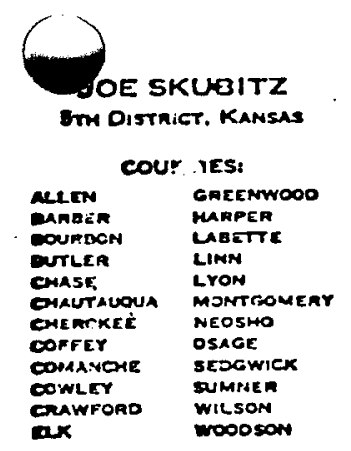

Comgrecs of the Umited Satates

Inouse of Xievrescntatibes

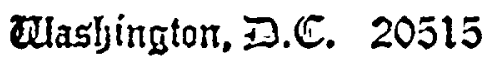

February 12, 1971

Honorable Robert B. Docking

Governor of the State of Kansas

State House

Topeka, Kansas 66612

Dear Governor Docking:

You are aware, I am sure, that the Atomic Energy Commission has requested from Congress an initial authorization of $\$ 3.5$ million this year and $\$ 25$ million overall to convert the area around Lyons to a permanent repository for the atomic wastes of the entire United states. This request will be considered shortly by the Joint committee on Atomic Energy.

It is my conviction that the state of Kansas should oppose this authorization at the hearing. The purpose of this letter is to solicit your support, the support of the cognizant state officials, and the Legislature to join in registering our opposition to making kansas an atomic garbage dump.

In taking this position, I owe you, as Governor, the Members of trie state Legislature, and my colleagues in the House and Senate of the United States congress an explanation. I have not come lightly to this decision to oppose. It is the end result of more than nine months of combing available facts. Indeed, it is this very paucity and unsureness of facts by those who are scientifically best informed that has in large measure compelled this proposal to you. 
Moreover, while I have a responsibility as a member of congress from Kansas to deal with Federal actions that affect and concern our state, it must also be understood that the Governor and the legislature of a state have an equally important role in certain circumstances. The Federal Government cannot compel a sovereign state to do itself and its citizens possible irreparable injury if its officials refuse to be stampeded and bow to Federal pressure. It is for this reason that I ask for careful consideration by the Legislature and by you of the problem and hopefully your subsequent support in opposition.

Let it be understood beyond any question that the issue is not the erection and operation of nuclear power plants. No one, certainly not $I$, is opposed to the installation of nuclear power plants, whether in kansas or in any other state, so long as safety and environmental factors are considered. Seventeen such plants are now operating in the United states and undoubtedly over the next quarter century or less there may be plants in every state. What I oppose and what I believe we must all oppose is making Kansas the dumping ground for the deadly atomic wastes of these plants.

With this firmly in mind, let us look at some facts and ask ourselves some questions.

The Atomic Energy Commission proposes to ship into Kansas eighty million gallons of dangerously radioactive "soup." This is a waste product from privately owned nuclear power plants. For transport and burial purposes, the "soup" must be converted into solid blocks. These blocks are hot inside -. 1800 degrees hot: And they will remain hot for hundreds of years: While the outside of the block at time of burial is held at 400 degrees, corrosion and deterioration of the container will take place in a few years. An additional minimum of three and one half million gallons will be accumulating each year over the next ten years from privately owned nuclear power plants now operating and to be operating all over this country. 
When Kansas was first suggested as the national dump for atomic wastes the state's Geological survey (I presume at your direction) and I promptly asked that the AEC initiate extensive studies on geologic stability. I asked that transportation risks be carefully analyzed. I asked for a survey of alternate sites in more remote areas of the globe, not just in the united states. I asked trat these studies be undertaken by the AEC and considered before definite planning went forward at the Lyons site. Incicientally, some of the geological observations by the kansas Geological survey raise important questions for all of us.

If the AIC studies and investigations and surveys have been made, they have, like so many other Atomic Energy commission affairs, been kept a deep dark secret. We faced a fait accompli when the commission's demand to the Budget Bureau for authority to buy 2,000 acres and to make preliminary plans for the Lyons atomic dump surfaced in congress.

In my view this is not a decision to be made unilaterally by the Atomic Energy Commission; it is a decision that directly affects Kansas residents and they have the right to know the facts, express their views, and indeed make the ultimate decision. Kansas has rights which even the Federal Government mus respect.

The wichita Eagle, in a perceptive bit of journalism on January 31, asked AEC Chairman Glenn seaborg some important questions dealing with the safety of the atcmic wasteburial proposal. To an Eagle inquiry on safety, for example, DE. seaborg said, "retrieval of radioactive waste if absolutely necessary" would be possible but concepts for such retrieval procedures have yet to be examined. Dr. Seaborg thus not only honestly admits the inherent danger of the burial plan, but his answer discloses the lack of thorough planning and research by the $A E C$ before choosing kansas as its atomic garbage dump.

To this day, so far as I can determine, no plans for retrieving the dangerous wastes in case of emergency have 
been developed even though the commission chairman admits removal may be necessary. Should Kansas accept AEC's "generous" offer and Congress authorize $\$ 25$ million based on this kind of research and facts?

Dr. Seaborg insisted to the Wichita Eagle in another answer that the lyons site will not be a national "dumping ground" because, he said, the wastes will be "carefully packaged, and will be emplaced in the repository in a very precise manner, carefully recorded and surveyed." But wastes are wastes whether they are garbage in plastic bags or 1800 degree radioactive blocks in stainless steel containers carefully packaged or r.st. And the danger of pollution to the air above anc tae water below rill continue to exist for a half million years, the period Dr. Seaborg says the waste will remain dangerously raaioactive for all living things.

What are the economic benefits that the Atomic Energy Commission promises us? During the construction phase jobs for perhaps 200 persons will be provided. Thereafter, Dr. seaborg suggests the surface "could be considered for such a beneficial use as a site for an industrial park." Why the area will be more attractive to industry with the wastes below than it is now is difficult to understand. Is it perhaps because the surface area will be warmer due to the tremendous heat underneath? We should ask ourselves why the Kansas salt beds were chosen for this questionable honor instead of other,. more convenient and larger salt beds?

Even the most casual study of the facts shows that Dr. seaborg has again hedged on other questions raised by the Eagle. Nuclear waste disposal directly involves transportation safety, a danger that could be substantially lessened by locating the disposal dump in the immense salt deposits of the Salina Basin of Michigan, Ohio, Pennsylvania, and New. York. This vast salt Basin lies almost directly under and adjacent to the large midwestern and eastern nuclear power plants that will be the principal source of future wastes. The Lyons site, on the contrary, will require transportation 
by rail over long distances, in some cases across half the continental United states. This will subject large parts of the population of this country to the risks of derailment, collisions, and similar accidents.

Consider, for example, a derailment as tragic as the Melvern, Kansas, accident of last fall that would involve a train load, or even a single box car, carrying 1800 degree radioactive blocks, material that will remain radioactively fatal for thousands of years. What would happer to Melvern, to the entire state of Kansas, indeed to a large part of the Midwest if such an accident should befall?

Dr. Seaborg promises that the AEC "will be working to reduce the likelihood of a rail accident; we will," he says, "maintain our high standards of containment should ain accident occur." Thus Dr. Seaborg agrees that accidents are likely. There can be little doubt that transportation accidents and accidents at the dump site will occur. Moreover, many AEC standards have been sharply criticized by atomic scientists who have studied such disasters as the loss of the submarine Thresher and the Rocky Flats atomic plant fire.

The state of Kansas has the right, even the duty, to evaluate, monitor, and insist upon a higher set of standards than those presently relied on by the AEC.

Most misleading of all is the suggestion that if Kansas agrees to becone the nation's atomic dump by permitting the construction of a tax-exempt federal facility, it will be doing the nation a "vital" service. The fact is that Kansas would be performing a "vital" service only for the privately owned nuclear povier companies of the eastern seaboard. Nearly all of the wastes of future years will come directly from the nuclear power plants of such companies as consolidated Edison of New. York, Detroit Edison in Michigan, and Commonwealth Edison of Illinois. There are no nuclear power plants in Kansas today. 
on the contrary, Kansas has six large and sixty-six smaller power plants all of which burn fossil fuels. All use substantial amounts of coal, oil, and gas produced within kansas. The great majority of power plants in this country use fossil fuels. The facts are that the use of coal, for example, for the production of electrical power has increased more than two-fold in this country in the past decade and continues to rise at more than $7 \%$ annually. The coal resources of this nation are immense. Estimates are that up to as much as one thousand years supply is currently available at present usage rates. Fossil fuels remain safe. The principal drawback of one of them, coal, has been air poliution, a problem that is now well on the way to being moderated and perhaps ultimately solved.

But atomic wastes produce high levels of heat, dangerous levels of radiation and the potential for a kind of horrible air, ground and water pollution that is beyond the present ability of mankind to control. Since we are dealing here with wastes that will remain dangerous for a half miliion years, who can be sure that underground water sources in adjacent kansas, indeed in the entire midwest lower river basins will not eventually become radiation contaminated. Certainly the Kansas Geological survey suggests this possibility. The AEC believes - - remember it cannot be certain - that the heat of the wastes will melt the salt and eventually provide a seal that the radiation will not penetrate.

It occurs to me, as it must to you. Governor, that if the AEC is so certain of its physics and chemistry theories, why are not other, larger and far more convenient salt beds in the united States proposed as atomic dumping grounds. Indeed, why dump in the United states at all? Surely there exists places more remote and much safer for mankind than in the center of the richest and most productive country in the world. Until all of us, including the experts of the Atomic Energy Commission, know more and are surer of theirfacts, I suggest that this is a safer course to follow. 
In summary, it behooves all of us to keep firmly in mind these facts:

1. The fact is that however the Atomic Energy Commission may phrase it semaritically, a part of kansas is proposed as a dump for the most dangerous garbage in the knowledge of mankind; a dump is a dump no matter how the garbage is packaged.

2. The fact is that the Atomic Energy Commission is itself far from certain of the safety of its proposed procedures for burying this atomic garbage.

3. The fact is that the Lyons project is not basically for the welfare of the United States Government, nor even in its entirety for the Atomic Energy Commission. It is rather a convenience for privately owned utility corporations operating nuclear power plants who are seeking a cheap means of disposing of dangerous wastes away from their own populated areas. Such disposition is as much a cost of doing business and a part of the final cost of electrical energy as is the construction of a smokestack to vent off the burning coal. The Federal Government does not subsidize waste product handing for private non-nuclear power plants. Why then should it subsidize the cost of handling atomic waste products for other private power plants who use nuclear energy?

4. The fact is that the atomic dump will be of no economic advantage to Kansas and Kansas people. The AEC predicts that peak employment some twenty years later may reach 200 persons. Some of these may be Kansans; a numiber of atomic technicians will supervise the burial of the radiation material as it rolls in from the country. No plants, no factories, no long-time economic benefits will flow. On the contrary the very presence of the atomic wastes may deter and frighten off prospective industrial plants.

5. The fact is that for reasons that remain somewhat obscure, the AEC doesn't want to bury the wastes in other, larger salt beds adjacent to and far more conve- 
nient to most of the existing nuclear power plants. If one reason is AEC concern for the large urban populations in those areas, then I share an equal concern for the more rural Kansas populations that will be exposed.

6. The fact is that some eighty million gallons of.hot, dangerously radioactive wastes are now in temporary storage in various places adjacent to privately owned nuclear power plants and AEC operated nuclear facilities in Idaho, washington, Georgia, and elsewhere. AEC is frantically seeking a permanent burial site because the containers are deteriorating rapidly. AEC tried Idaho. and that state's senators came in with a loud "no." For reasons not yet clear it can't use washington as a permanent site. It settled on nice, quiet, clean kanisas as a likely place. Kansas, it is assumed, might buy the subtle propaganda that we were really being honored to be chosen.

7. The fact is that the Federal Government shows more concern for Okinawa than it does for kansas. Residents of this far-away pacific island which we are abandoning as a military base protested the continued storage on their land of mustard gas left over from the korean war. At great cost for repackaging, the pentagon shipped, hundreds of tons of mustard gas to tiny Johnston Island, a coral atoll in the western pacific, for burial there. In my view, what is good enough for okinawans is good enough for Kansans.

I regret that this letter is overly long but I felt it imperative that you, as Governor, the Members of the Legislature, and my colleagues have before them this condensed review. My research has convinced me that a prudent consideration of the available facts inevitably must lead to rational opposition to a project that would make our state the future and permanent home of our colintry's atomic garbage. I will 
appreciate your usual courtesy in advising me of your position and the course of action you will follow.

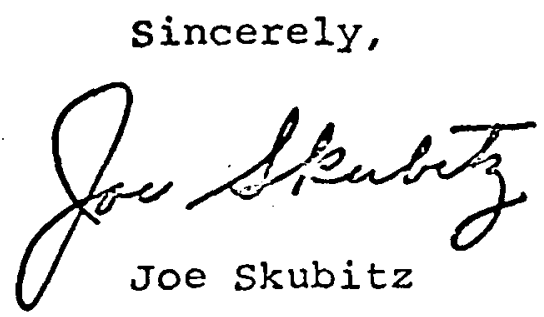

cc: Each individual Member of the Legislature

Hon. Robert J. Dole

Hon. James B. Pearson

Hon. Garner Shriver

Hon. Larry Winn, Jr.

Hon. Keith sebelius

Hon. William Roy

Each individual Member of the Joint Committee on Atomic Energy

Dr. Glenn T. Seaborg - Chr. AEC

Dr. William B. Hambleton - Dir. Kansas Geo. Survey 


\section{DEC $17 \quad 1870$}

Honorable Jains B. Deerson

United States Ecnate

\section{Dear Snnetor Zoarson:}

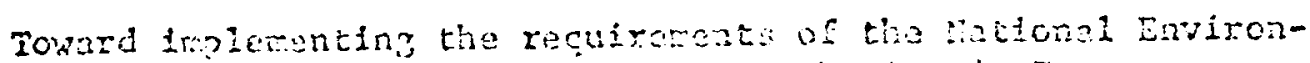

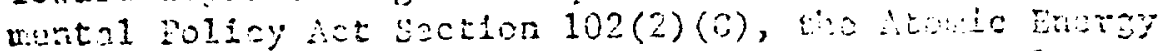

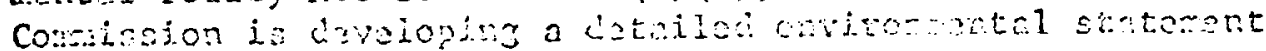

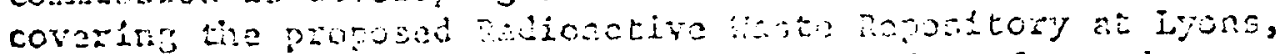

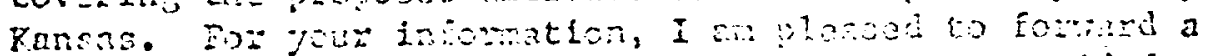

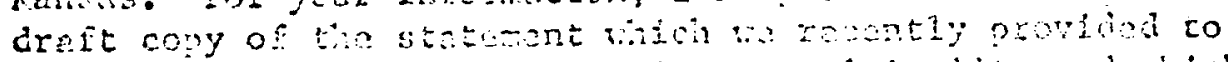

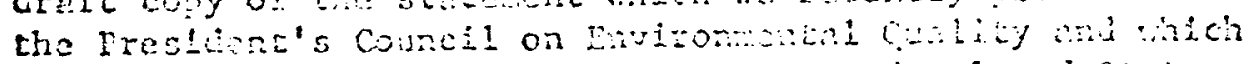

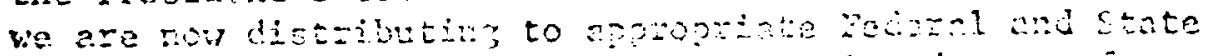

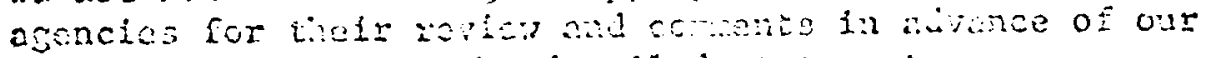

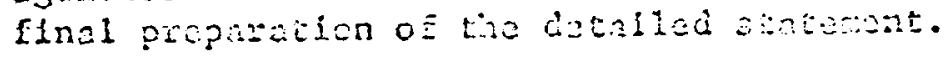

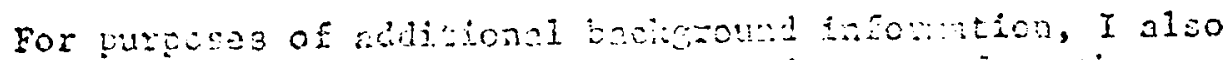

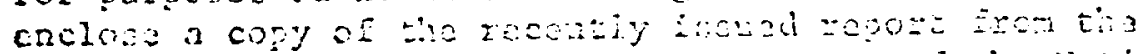

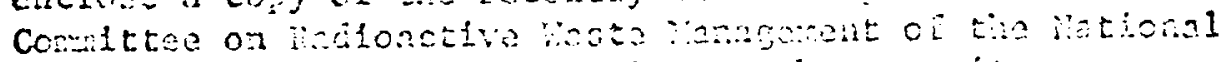

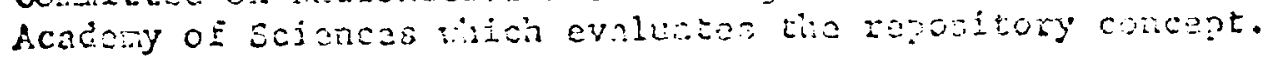

If you costro nduitional informaton, y- w1l be ploseod to hear irco you.

\section{Sincerely,}

Signed, Ioth A. Erlwizize

John A. Erlavina

Assision: Canzral ianaser

tor Gusations

\section{Enclesurzo:}

1. Drafe Environiantal Statemant

2. Nat'1. Scackay ö Sciancas sot.

Identical letters sent to: Senators Gravel ( 5 cys); and Dole and Representatives Sebelius, Mize, Winn, Shriver, and Skubitz. 
UNITED STATES

ATOMIC ENERGY COMMISSION

WASHINGTON. D.C. 20545

Honoiable Joe Skubitz

House of Representutives

Dear lor. Slrubitz: :

This is to inform yoi of ongoing activities pertaining to the proposed salt mine repository et Ljons, Kensas. In ordar to obtain a better definition of the project for cosi and safety purposes, the Comission has requested proposals from several firms to perform the concenturil ciesign work for the fecility. Three fims have subnitued proposels to do this vork. They are the joint venture of Fennix 2: Scisson and Fesle-Picher Industries of Iulsa, Oklehora; Resources Sciences Corporation of julse, Oitlahone; and Kaiser Enginea"s of Oallend, Californic.* A Contrect Evalustion Boa'd has been esteblished by our Cak Ridge Operations Ofïice for the purpose of revieving and . evalueting these pronozals. The Board's evaluation has been received and atrand of $a$ contract to the succesaful proposer is expected shortily. The successilil proposer in cooperation with the Oek Ridge liational Laboratory is expected to frepare the conceptual design report, and a target date of about Hoveriber 15, 1970, lias been set for this report.

In connection with work at the Lrons site, the ransas geologic survey hes initiatcd drilling for shallow hydrology holes of approxinately $100 \mathrm{ft}$. depth in the area of the proposed site. In addition agreenent hos been reached on the location for additicis I coring and drilling operations required for geologic studies, and. drilling specifications are now being developed. The Comps of Engineers has been requested to acquire the necessary rights of access and to undertake the drilling operations, the results of which will be analyzed by the Kansas Geological Survey and the U. S. Geological Survey. It is anticipated that these drilling operations vill. cournence about August 29, 1970. Also as part of the preliminary activities in comnection rith the acquisition of the site folloiring authorization of this project, the Corps of

* These proposals inclucle the Carcy Salt Co., Hutchinson, Kansas, on a consultant or subcontractor basis. 
Engineers has been requested to prepare a pianning roport on the status of title and the cinerships of the property to be acquired, and also to furnish a prelirainary appraisal of the value of the land and land rights involved. This planning report is expected to be availabje sonetime after mid-September.

Concurrently with this effort, the Oak'Ridge National Laboratory is preparing a draft safety analysis report on this project. ORIL has also prepared a draft environmental impact statement which is currently undergoing review in AEC Headquarters to meet the requirements of section $102(2)(C)$ of the National Environmental Policy Act of 1969.

Independently of these efforts, the Committee on Radioactive Waste liarlagement of the National Acodemy of Sciences is preparing a report evaluating the salt mine concept and commenting on proposed geoloric studies. This report is expected to be available in the early fall.

In order to keep the public fully informed on this project and particularly the residents of Kansas, we are prepared to provide additional briefings, similar to that held in Iyons, Kansas, on Wednesday, July 29, 1970, at which Governor Docking and concerned citizens of Kansas and the press were afforcied on opportunity to discuss the proposed repository with representatives of AEC and ORIN.. Based on local desires in this matter, ve plan to give a. briefing by invitation at Salina, Kansas, in Septemiver; and we are in a process of working with the Lyons Chamber of Cornerce for a townhell type discussion in October. At about the sarne time, we are proposing an industry-wide briefing at Lyons for firms who are interested in this project. We expect to solicit industry participation and cooperation in all stages as the project develops.

On August 27,28 , and 29, the Oak Ridge National Laboratory is providing to representatives of sevenal arencies of the state of Kansas, who are concerned with this project in protecting the interest of the State, a complete technical briefing to enable then to better understand what is being proposed at the Lyons site. 
It is cur cesire that informetion recerding this projent bo mesc fully and freely available to the publjc, and ve wre exerting. every cffort to sce to it that it is conducted under full pubitic scrutiny.

We shall continue to keep you inforned of significant developinents.

Sincerely,

Signod, John E. Eirerino

John A. Frichine

Assistant Genora? kangere

for Oparations 


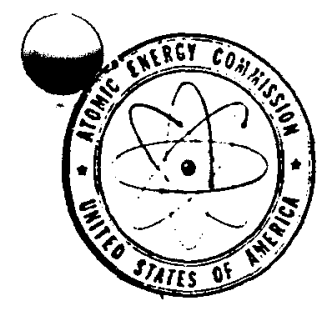

UNITED STATES

ATOMIC ENERGY COMMISSION

WASHINGTON. D.C. 20545

AUG -81970

Honorable Joe Skubitz

House of Representatives

Dear Mr. Skubitz:

Thank you for your letter of July 28, 1970 concerning the proposed project to establish a repository for solid radioactive wastes in a salt mine near Lyons, Kansas. As requested, we will comment on your suggestions and questions.

You urge that the Atomic Energy Commission "make known to al1 Kansas citizens the exact nature of the risks and dangers involved" in the proposal for the repository. This has been our intention from the outset. AEC procedures require the preparation of a hazards analysis report on a facility such as the proposed repository. Preparation of such an analysis is already underway by AEC's Oak Ridge National Laboratory (ORNL). This analysis report will provide the type of information about risks which you request, not only for the use of citizens of Kansas, but also for review and study by experts and advisers to AEC including the statutory Advisory Comnittee on Reactor Safeguards.

\section{Safety of the Kansas Salt Formations as a Disposal Site}

We believe that there is much less disagreement "over the accuracy and adequacy of scientific data gathered in regard to the Lyons site" than is suggested in your letter. A great deal is known about the general geology. of the Lyons area thanks to past work of the Kansas State Geological Survey (KSGS) and the U. S. Geological Survey. AEC has proposed from the very outset of the project to drill holes on and about the proposed site to confirm that the geology of the precise site does in fact conform to what is expected. Dr. Hambleton (Director, RSGS) has been and is being closely consulted about how many and where to drill such holes and his organization will help review and evaluate the results.

The statement that AEC has given Dr. Hambleton a deadline of November 1 , 1970 to complete the portion of the geologic studies being undertaken by the KSGS is incorrect. We have learned on inquiry that ORNL has asked $\mathrm{Dr}$. Hambleton for a progress report as of November 1, 1970 but no completion date has been specified. 
It should be noted that virtually all of the geologic studies, both short and long range, were proposed by AEC and ORNL even before the KSGS became actively involved in the project. A number of the studies referred to in your letter have been underway for months and preliminary reports are already available.

Only a few of the proposed studies are of such a nature as to provide information pertinent to the question of whether or not the Lyons site is or is not safe. Some of the studies will be of a continuing nature for years to record data about the ecology of the site area as baseline information to determine in the future whether or not the operation of the repository has any effects on the environment. These cannot be completed in the 18 months to which your letter refers.

Other studies referred to in your letter, such as regarding the probabilities and possible effects of some future glaciation at the site or of salt erosion of the flank of the salt bed some 35 miles from Lyons, are underway. Preliminary information from these studies indicates that such remote possibilities, to the extent they can be realistically evaluated, will not offer significant safety problems for the Lyons site.

Also, AEC has asked the Committee on Radioactive Waste Management (CRWM) of the National Academy of Sciences to evaluate the salt mine concept and to comment on the necessity for and timing of additional geologic studies. Dr. Hambleton is a member of the Salt Mine Panel of the CRWM and his suggestions and comments are being considered by that Committee in its deliberations. We will furnish you a copy of the report of the Academy Committee when it is available.

Your questions regarding possible shattering of salt, referred to in a 1967 report by ORNL staff members, have been replied to in Mr. Erlewine's letter of July 31 which you had not received when you wrote to me.

With regard to the specifically-numbered three questions in this section of your letter:

1. The proposed project, if authorized, will be a project of the Federal Government and will be constructed and administered by AEC in keeping with its responsibilities for the safety of the 
citizens of Kansas and the nation. AEC does not intend to permit any radioactive wastes to be placed in the facility until it has been determined that the facility is suitable. However, once the facility is in operation it will be serving an important function for the entire nation and it would be in the national interest to use it for the purpose intended unless objective evidence developed which would cause its safety to be reconsidered. The proposed acquisition of approximately 1,000 acres of surface land would constitute the extent of the repository. Some additional underground salt and mineral rights will be acquired around the perimeter of the surface acreage to assure that the repository is not disturbed.

AEC has encouraged State participation in the planning for this project to date and we intend to cooperate closely with appropriate State officials during the operation of the facility.

2. The large shielded transportation casks are only intended for transportation and have never been intended for mine storage. The wastes will be in metal containers when placed in the holes in the salt but the primary long-term container will be the salt itself. The heat levels in the salt from the stored wastes will be well within safe limits for effective containment by the salt.

3. The remote possibility of heat rise due to metamict effect has been studied by ORNL and is being reexamined once again by the Laboratory from two standpoints: a) is there any credible possibility of the effect occurring in the salt and $b$ ) were it to happen would it make any difference to the integrity of the repository? Priority attention is being given to these suggested possible problems so that answers will be available in the near future.

\section{Safety in Transportation of Radioactive Wastes}

As stated earlier, AEC procedures require the preparation of a hazard analysis report for projects such as this. The procedure applies to transportation methods as well as facilities. AEC has consistently taken the position that in the transport of radioactive materials, they must be so packaged and transported as: to assure that if involved in an accident the wastes will not be released to contribute to the consequences of the accident. This approach will govern the transport of the radioactive wastes to the repository. 
Since nuclear power plants and fuel reprocessing plants are being constructed or planned in many areas of the United States, it is imperative that there be safe methods of transport for highly radioactive materials. Such methods do exist and AEC has a long and excellent record of experience of safe shipments.

Any initial waste repository, wherever located in the United States, will require shipments of wastes to it from varying distances and through many states. It is not feasible to propose simultaneous construction of several repositories in different areas. Even if one were to attempt it, much time would be required to identify specific locations that might possibly offer geologic conditions that would be equivalent to the Lyons site. More time would be required to acquire firn geologic data equivalent to that known about the Lyons site.

III. The Responsibility of Kansas in the Development of Nuclear Power

Your letter suggests that the public accepts the risks of nuclear power plants because these have been stated and explained and such risks are balanced by apparent benefits. "It seems, therefore, that because we are a democracy, the public should be informed of the exact nature of the risks, then they can weigh these against the benefits, and decide the nature of the safety. At present, it would appear that the Atomic Energy Comission is making this decision for the public by announcing that their proposal to dispose of nuclear waste material in central Kansas is 'safe'."

The AEC is very much interested in the public knowing all about the proposed salt mine project. We are making every effort through printed information and public meetings to provide information. We are not aware that AEC has "announced" the project as safe, although we certainly believe it to be so. We certainly would not propose a project which we believed to be unsafe.

Please note the opening paragraphs of AEC's news release dated June 17, 1970 about the selection of the Lyons site:

"The Atomic Energy Commission today announced the tentative selection of a site near lyons, Kansas, for an initial salt mine repository for the demonstration of long-term storage of solid high-level and longlived low-level radioactive wastes. 
Over the next year aditional geologic and safety studice vil] be conducted to confirm that all aspects of the operation at this location can bi done safely."

Note that the selection is sajd to be tentative and that geologje and safety studics are to be conducted. Tt is necessary to pick a site in order to sturis the geologic dictajls of that sjte. Such data are necici so that the andysis of rislis can be completed. Ihus it would seen that $A E C$ is trying to do cractly what you are asking jt: to do. Jt is our intent that the publjo be fuldy jnforied.

However, even when the public has been inforaed the responsibility for decjsjon on speciric projects is that of the coverment. Th this instance the congress mot authorye and appropjate furds for the repository jif it is to be constructed. The fic must be able to assure the Presjomt and the congress, who act on behalf of the public, that the project wjll be safe and in the natjomal jutercst.

With regard to your question about why kansas should or should not want such a facjlity jocated within jts bordejs: Your letter jmpljes that wase cijsposal and pollution control are a proper concern only for the Jocal comminty wich benceits from the intustrial. source of the waste or pollution. be fear that the evidence je becoming over. whelming the pollution doesn't reconjes poljtical bouncaries and that vaste cijsposaj mey be more than localjijes can handlo whasistect. Certainly the goneration of electric encrgy, whether from nuclcat or conventional plants, is of national concegn as valu as state and local interest. Storage and djsposal of nuclear vastes warant the best national soluijom. Jite lyons, kanses site his been recomanded becatise, based on the best scicntific acivice avajlable, jt offers the safest geologic features lnown to AIC for the initjal repository.

AEC has not urged that Kansas accept the faciljty because of the sone 200 jobs involved with the facility. However, people interested in the project, including you, have asked AEC how many jobs will be jnvolved and we have given our best estinate. The \$25 million construction cost estimate covers only site acqujeition, desicen and construction; it does not provide for research and developinent.

On page ten of your Jetter it is stated that: "Jf Kansans are cxpected to assume the risks of storage of nuclear vaste micrial, why can't they also expect to receive the direct benefits providied by a ruclear 
power plant? This could mean 50,000 jobs, general attraction to many new industrial enterprises and a real economic boost to the entire state of Kansas."

Perhaps the number " $50,000 "$ is a typographical error if intended to refer to the employment for a nuclear power plant, but we would like to point out that even the very large nuclear power plants have only about 300 employees in their operating crews.

AEC would be pleased if the utilities of Kansas decide to embark on a project to construct a nuclear power plant in that state. However, such a decision must be made by utility companies. AEC can only

license a plant, not make the determination to build one or to select its location.

The Commission appreciates your interest in the repository project. We hope that as you continue to study it, you will conclude that it is an important national project which can be safely constructed at Lyons.

\section{Cordially,}

(Signed) Gern T. Seaborg

Chairman 


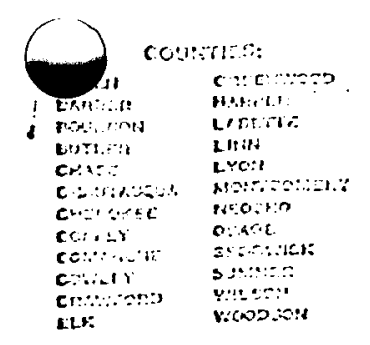

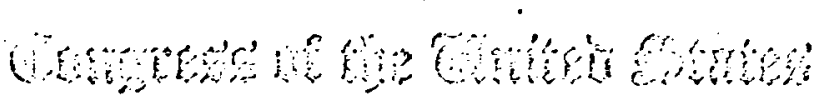

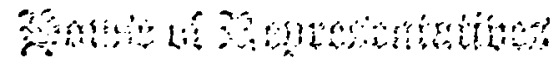

$$
\begin{aligned}
& \text { Comisto, } \\
& \text { July 28, } 19 \%
\end{aligned}
$$

Dr. Glerm T. Seaborg

Chajmian

U. S. Atonic Energy Comnission

washington, D. C. 20545

Dear Dr. Seaborg:

In view of the growing volume of conflicting opinions on the safety of nuclear waste disposal, I urge you to make known to all kansas citizens the exact nature of the risilis and dangers involved in the recent proposal of the Atomic Energy Commission to bury this nation's atomjc wastes in the salt mines of central kansas. Jhe tenaijue selection of lyons, Kansas, as the site for this disposal project raises three arcas of concern: I. Safety of the Kansass salt Fonmations as a Disposal site, Ir. Safety in Transportation of Radioactive wastes to kansas, and III. The Responsibility of kansas in the Development of Nucl.car pover. I woula appreciate your corments on the following facts:

\section{Safety of the Kansas salt formitions as a Disposal. Site}

Because mary of the wastes to be deposited must remain uncisturived for 500,000 years, there is an important need for scientific agreement on such basic factors as the geologic stability of this area and the effects of the intense heat on the salt. To date, there is remarkable disagrement over the accuracy and adequacy of scientific data gathered in regard to the Lyons site. The following examples are parificularly outstanding:

ITEM 类. In a letter to me on June 11, 1970, .... John Erlewine, Essistant General Vanager for operations of the $M \mathrm{LC}$, states, "Consideration of Kansas as a site for the initial demonstration Federal waste repository is 
Dr. Glonn T. Seaborg

page Tivo.

based on the favorable geologic characteristics of the Kansas salt bods and our rather extensive knowledige of the area:" In nentioning this opinion to Dr. William Hambleton, Director of the Kansas state Goological Survey, and asking him if he agreed, Ilambleton responded, "I do not agree that there is extensive geological knowledge of the area," (July 9, 1.970); and in addition, The Jnterim Report of the Kansas Geological survey on storage of Radioactive waste paterial in salt at Jyons, kansas, July 7 , 1970, states, "In gerieral, studies related to the lyons, Kansas site have bocn developed from a simplistic view of the geology... The geology of the area is not known in sufficient detail with respect to structual or stratigraphic characteristics."

ITEM $t^{2}$. John Exlewine states on behalf of the AEC, April 24, 1970, that a disposal facility reax central Kánsas would be "safely isolated from fresh water aquifers for geologic periods of time and offer effective protection against accidental contact by man or animals.". Again, in a news release of June 17, 1970, in announcing the. selection of Lyons, the $A E C$ indicates, "...salt deposits are frce of circulating ground waters and completely isolated from underground aquifers by esscntially impermeable rock." However, Dr. Hambleton of the Kansas Geologic survey points out, "We have very little information on the subsurface geology and on water quality or quantity... There are indeed underground areas of water near the proposed site, but little information is available." And the Kansas Geological Survey Report states,

During the past million years, for example, the effects of glaciation have produced marked change in ground-watex systems, and erosional rates. The longterm possibility of the salt being subject to solutional activity, erosion, or other stresses, cannot be ignored.

Significant base-line information on water quality and quantity in nearsurface rocks and rocks above and below the salt is not available. 
Dr. G] emin. T. Sciborg

page Three.

Therefore, after consjdering the long-range effects of the radionctive waste disposal project, j.t would seen that a large volume of complete and accurate facts relating to the geosraphical siffety of the area is needed before any kind of an approvil can be given to $A E^{\prime}$ 's proposal. I understand that the Atonic Energy Comission has agreed to work with the kansas Geological survey in rogard to gather-ing more complcte geologjical infornition. But I also note that the AEC has given the Kansas ceological survey a. deadine of November 1 - a mere three months ..- to complete a study which the chairman of that survey, Dr. William Hambleton, estimates will take 12 to 18 months to be conducted aclequately. I usge you agoin -- considering that the effects of this waste disposal project will extend for 500,000 years - to take the time needed to gather a large volume of complete and accurate facts about the state of Kansas. A decision involving the safety of future generations should not be made in haste, yet neither shoula we react out of fear.

Besides the geology of the region, other questions arise as to the safety of the proposed site. I am very much concerned about the amount of knowledge and information avaijable concerning the effects of heat on salt. In "Disposal of High-Jevel Solidified wastes in salt Mines," a report by W. C. McClain; R. L. Eradshaw, and F. M. Lmpson of Oak Ridge National Labratory and published by the International Atomic Fnergy Agoncy, Vienna, 1967, in Disposal of Radioactive Wastes Into the Ground, it is stated at 55].,

Some bedied salt, including that in

Kansas, contains small amounts (less than $1 / 2 \%$ ) of moisture in the form of small intracrystalline brine inclusions. This property had been assumed to limit the maximum allowable salt temperature to less than 250 degrees $c ;$ since, above that temperature, internal vapor pressure causes a violent shattering of the salt. During the experiment, it was discovered that these brine inclusions will migrate toward the heat sources under the 
Dx. Glcmin $\mathrm{i} \cdot$ Sworg

page Jour.

influence of: the themal gradients.

since a large volume of salt is heated

appreciably, a consicierable volume of

water is involved.

According to the news release of ABC, June 17, 1970, project salt vault, conducted at Iyons from 1965 to 1967 , "demonstrated the safety and foasibility of handing highly radioactive wastes in an underground enviroment, determincd the absence of detrimental radiatjon or heat effect on salt..." Iess confident of the safety in this regard is; the Report of the kansas Geological. Survey which states,

According to design specifications, the temperature in the salt surromding storage containers of high-level radioactive waste vill. not exceed 200 degrees $\mathrm{C}$. However, radiation danage studies suggest that the radiation crersy can be storca in the materials containing the waste products, and that this energy can be released under appropriate temperature conditions. This metamict (wigner) effect could result in temperature increases to an order of magnitude of 800 degrees $C$. Temperature markedIy affects the flowage characteristics of salt. Furthermore metamictization usually is accompanied by a volume expansion. The effect of this expansion on site integrity requires evaluation. A further cause for. concern is the oxygen produced by neutron and protron bombardment by radiolysis. The possibiljty of the metamict effect and uncertainty about the effect of a marked temperature rise is a matter of concern.

The above statements directly relating to the safety of disposal of radioactive wastes in salt beds indicate more than mere minor discrepencies over factual. details of the proposed Iyons project. When such a basic problem as the amount of heat actually involved remains outstanding, 
Dr. Glenn T. Seaborg

page Five.

it is difficult to give a favorable disposition to AEC:s proposal.

In adation to the major questions raised above; the people of Kansas have a right to know the answers to the following questions:

1) Will Kansus have control. over the amount of wastes brought juto the state? Since quantity of wastes directly relates to the amount of heat given off, and conseguent]y, relates to the total acreage needed to store the wastes, this factor is important when the citizens of Kansas decide they have had enough: of the waste naterial.

2) Why will the wastes be dumped directly into the salt without the benefit of lead or concrete shiclding? I understand that the wastes will bo brought to kansas in 100-ton lead casks but that these casks will bo removed and the wastes will be ceposjted directly into the salt in Kansas. How can this proposal be consiciered safe in view of the possible effects of heat on salt?

3) Will there be a significant rise in ground temperature above the disposal area? At present, the design of the disposal facility is based on an estimated maximum heat of 200 aegrees $c$ within the mine. This is not expected to cause a significant rise in ground temperature. However, what wilj. happen if due to the netanict (rigner) effect the heat of the waste material reaches a magnitude of 800 degrees $C$ ?

I recognize that the issue of disposal of atomic waste material is susceptible to emotional attack and misinformation. However, valid criticism should not be cast aside as an offshoot of an extremist's attack. Responsible criticism can strengthen valid argurient, and the most valuable contribution to be made by the scientific community at this time is to provide the laymen with complete and accurate facts on the safey of atomic waste disposal. The people of Kansas should be made aware of the exact nature of the risks involved in the AliC's proposal so that 
wr. Glenn re fuores

page Si.r.

they my decicic for themselves whether or not they vant to take the risk of this nuclear waste disposal project.

\section{IJ. Sefety in Iryansportation of Radioactive Wastess to Kansas}

The proposal of the Atomic Energy Commission to bury the nation's atomic wastes' in the salt mines ncar lyons, Kansas, is not limited to the safety considerations of those persons living in the imnediate vicinjty of Lyons. Because these wastes must be shipped by rail and highway routes to the site at Lyons, all persons living near these routes bill have an interest in the design of safe transportation. The danger of the waste is best demonstrated. by the need to bury it 1000 feet below the earth's surface in 300 feet of salt.

In its Report, the kansas Geological survey recommends contingency plaming for "worst possible case" conditions. BY this crjteria, one might study the $\mathrm{ANC}$ 's transport contajrers from the view that we may one day expect an oil car explosion near a car loaded with atomic wastes. . or even something worse. Minat could be the effects of this kind of accident on the surrounding community? What would happen, for instance, if this accident happened while the wastes were being transported through Kansas cj.ty. or ropeka?

Because the Atomic Energy Commission cannot guarantee that freak accidents will never occur--as the Thresher incident dramatically points out--the Kansas citizen has a right to know exactly what kind of risk he is being asked to take. The people of kansas should know why their state, located one thousand miles from the source of waste creation, has been chosen as a disposal site instead of using the salt beds of the castern part of the United States where, at present, the heart of the nuclear industry is located. It would scem that the risk--and even the cost-of transportation could be reduced to a minimum by selecting an injtial depository sjte in these beds which underlie the prescnt nuclear power plants. I understand this 
Dr. GJem r. Suborg

page Sever:

salt formation, knom as the Sajina Basin, rivals the Kansas site for size and consistency.

In a letter to ine on June 30, 1970, John Erlewine of the $\mathrm{ABC}$ stated, ". . ABC contemplates that in time there would be perhaps a total. of four or five such repositories located throughout the united states." irow, if at present kansas is assumed to be so geologically safe as to justify a thousand-rnile shipnent of wastes to the jyons site, what is expected to happen geologically to the other sites over the next few years to allow the $F_{2}$ LC to contemplate their development and, by implication, their geological safety? If there is some expected danger which calls for experimentation in Kansas rather than at a site much nearer the source of the wastes, then kansas citizens should be carefully informed of that danger.

III. The Responsibility of Kansas in the Developwent of Nuclear power

of course, the primary concern with the proposal of the Atomic Energy comission is centered on the scientific safety of the disposal site and the means of transportation to that site. I have indicated this by discussing these topics first in this letter to you. But now I turn to a consideration of the responsibility of Kansas in the devel-opinent of nuclear power.

Let me begin with a consideration of the nature of risk. While science mey be able to establish a certain amount of "safety" in nuclear waste desposal, it is assuned that no one will. ever be able to guarantee that no accident will occur. Therefore, there is an element of risk involved in the production of nuclear power. This risk was best described by the Brookhaven National Laboratory in The Theoritical possibilities and consequences of Micjor Accidents in Large Nuclear Power plants, 1957. Here it was estinated that a major accident at a nuclear power plant might result in: 1) 3,400 deaths at distances up to 15 miles and 43,000 injuries at distances up to 45 miles, 2) property damage of as much as seven billion dollars, ano 3) lanci contamination at even greater distances. Yet, the public is will- 
Dr. Glem T. Seuborg

page Eight.

ing to accept the risk--knowing what it is--because they also kno:: and enjoy the benefits of the producition of nuclear power. The benerits are more johs, lower electrical bills and a higher economic standard of living in their area because of the presence of the power plant.

In addition to the benefits of the porer plants offsetting the risks, it is assumed that the risks are further reduced by the caution taken by plant managers in the handling of nuclear elements.

Now what may be observed by our experience in the atomic world up to this time is that while the dia gers are great, they may be made remote, and the public is willing to accept the risks because of the benefits prociuced. "Safety" becones rather relative. It is a term dependent upon risks vs. benefi.t. While science can tell us ways to reduce the risks in handing nuclear products, it cannot guarantee the absence of $\mathrm{risk}$. It seens, thexefore, that because we are a democracy, the public should be informed of the exact nature of the risks, then they can weigh these against the bencitits, and decicie the nature of the safety. At present, it would appear that the Atomic Energy Commission is making this decision for the public by announcing that their proposal to dispose of nuclear waste material in central Kansas is "safe."

Now we come to the responsibility of Kansas in the development of nuclear power. It is frequent that one meets the argument that the people of Kansas owe America the duty of storage of nuclear wastes in order to develop this nation's nuclear power. But this is a rather emotional approach to an already nervous subject, and it is also open to flag-waving patriotism. In essence, the production of atomic power is a business, owned and operated by private individuals in a profit-incentive economic system. The production of energy at a nuclcar power plant provides jobs and electrical benefits directly related to the inmediate community in which it is located. Like any other industry, there is a waste by-product which must be disposed of at the expense, as it has turned out, of the 
Dr. Glenn T. SGriborg

page line.

cominuity which protited from the industry. communitios with coal-burning plants must put up with soot and smog. Coniunities with small products mills usually tolerate-or at least suffer from-water pollution.

Now we enter an age where the pollutant factors-the industrial garbage--is too dangerous to dump into the rivers or spew into the air. Radjooctive wastes in the Nucjear $\lambda g e$ must be disposed of where man and arimal wjll not inadvertently come into contact with these wastes. They are hot and rodiant and must be stored for thousands of years until the danger has passed. This pollutant of the Nucleax Age has its greatest danger in the risis of transportation and storage, and it is a risk which is associated with and must be weighed against the benefits of private industry--private production of nuclear power.

With this in mind, the question of Kansas' responsibility becomes: "What duty does kansas owe to private industry Jocated a thousand miles from its borders?" It. seems that kansas, wich has not contributed one microcurie to the growing heap of niclear waste matter, is now bejng asked to assume the risk of storage of all of these vastes in return for "an estimated 200 jobs." In addition to the risks, nearly 2,000 acres of land will be permanently retired from the state's tax roles. The AEC will be charging private industry for the cost of transportation and storage of the wastes, but Kansas will not receive a single dollax of this charge. Why shouldn't private industry, like consolidated Edison of New York, be subject to Kansas taxation--or payment in licu of tares--for the use of Kansas land in disposing of their wastes? In the final analysis, at a reduction in state revenue and at a risk that -will remain for five hundred thousand years, the people of Kansas are offered "an estimated 200 jobs." These benefits for Kansas are even less attractive when examined in detajl. The people of Lyons have been led to believe that this project will be a 200 job-boost "industry" for their community. But in conversation with Erlevine, I am told that the 200 job estimate is a maximum "possj.ble" figure based on a "future" time whon the plant is operat- 
Dr. Glom T. arborg

page ion.

ing at full cepacity. In reality we are talking about a possible fifty jows and evon these are likely to be highly skillac jobs. Miblt I would like to know is how many jobs will actually be provided for the people of the ryons conInunity?

The apyropriations figure of $\$ 25 \mathrm{million}$ is also quoted froguently as a measure of the size of this project. But again, won't nost of this money be spent on "research and development," ox acguisition or land and a relatively small amount on construction?

Even if the AEC's "projected" benefits could be taken at face value, they are small compensation inceed for the amount of risk to be assuncd.

If kansmins are expected to assume the risks of storage of nuclear waste material, why can't they also expect to receive the direct benefits provided by a nuclear power plant? phis could mean 50,000 jobs, general attraction to many new industrial enterprises and a real economic boost to the entire state of kansas. But at this time, kansas has not been suggested as the site for a single nuclear power plant--and even more discouraging, the prospect of future plants for the stato is not even hopeful. In a statement of: expected growth of the nuclear industry. associates at the oak Riage National Laboratory estimated that expansion planning was definite for the rest coast region, Southeasterr unitea states, and Chicago, Illinois, area. Kansas was not even seen in future plamning. The suggestion has been made that if kansas accepts nucloas waste, it will be opening the door to nuclear inciustry. But I think it is a strange way to cricr the ruclear Age by becoming the garbage paii for the nation's private nuclear industry.

The responsibility of Kansas in the development of nuclear power is to encourage the location of this new industry within the state. To locate a nuclear power plant in Kansas vould allow Kansas people the direct benefits of nuclear inaustry while reactor wastes could be 
Dr. Glonn T. Seaboxg

poge linevion.

stored with minimat. transportation ristis by using the liyons site. Tine rtonic snergy comission, as the yreatest yomoter of the nuclear industry in the united states, has the sole power to grant a license for operation of a nuclear facility. $6 \mathrm{j}$.th this power, they approve of the locations for nuclear power plants. The selection of Jyors as a possible disyosal. site provides substantial. reason for encourdging nuclear industry to locate in the state of Kansas.

In the final analysis, if the present generation can promise future kansas generations the risks of waste disposal, let them also promise the benejits of nuclear power for kansas. This promise should be nore than mere conjecture or speculation. There js the responsibility of make it a reality.

I conclude by rajsing the question: "Why was kansas chosen as a site for the disposal of nuclear waste matejial?" was jt because of the unhappy situation that has ariscn in the state of Idaho? Is this the reason the Kansas project has been placed on a rush schedule? Was Kansas chosen on the basjs of the popular notion that this state with its vast prairies and lack of ciensely populated areas would provicie the least resistence to the danger and degradation involved in beconing the nation's nucleor garbage dump?

Kansas citjzens will recognize that this nation stands on the threshold of a scientifically advanced and exciting Nuclear Ase. It has been estimated that the amount of fuel-energy to be used in the nert twenty years will be more than the amount used fron the time of the American Revolution to the present day. The great bulk of this energy will be produced by nuclear power plants. The people of kansas may be expected to encourage the development of atoinic power, but they cannot be expected to suffer the risks of a Nuclear Age without enjoying the benefits of the Era.

If the unanswered questions about the geological safety of ransas are setiled and it is adequately determined that the salt mines of Kansas are relatively safe 
Dr. Glemr Seaborg

page Tuelve

for future accumulation of wastes, Kansas will accept the necesscicy ristas irvolved but only if she receives the benefits of further progress in the Nuclear lige through power facilities. In addition, jf atonic waste, produced in privatejy-owned power plants, is to be stored in Kansas, and if the government bjll be charging for this service, then the govermont facility should be subject to state taxation, compensating payments to the state of ransas in lieu of taxation.

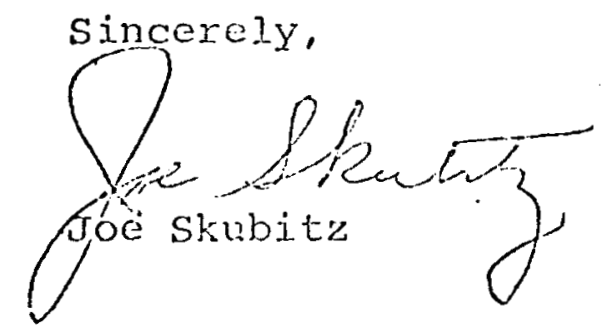


Honorable Joe Skubitz

House of Representatives

Dear Mr. Skub1tz:

Thank you for your letter of July 14 concerning the proposed radioactive waste repository near Lyons, Kansas. I shall attempt to respond to the questions in the order set forth in that letter.

\section{Page 1 paragraph 2}

You requested a copy of any geologic study which compares the Kansas salt beds with other salt formations. Enciosed is a copy of a report prepared by a staff member of the Daic Ridge iJational Laboratory entitled "The Utillation of liock jait Deposits of Central Kansag as a Repository for Radioactive Wastes." This report, I belleve, glves the type of information requested. With regard to your concern about shipeent of wastes, it showid be noted that nuclear power plants, which are che source of high-level radioactive vastes, are being constructed or planned in many areas throughout the United states. The highly raciloactive epent luel. elements from such plants must be sinipped, often for long distances, to fuel reprocessing plants where fission product wastes are removed. Thus shipment of highly radioactive solfd rateriale is a basic feature of the growing nuclear power industry and is not unique with regard to the proposed repository in kansas.

Based on information currently avallable, the AEC does regard the bedded salt formations of Central Kansas as having advantages which outweigh the additional cust and risk of transportation of the vastes. Transportation of these solidified wastes to a centrai repository which has been constructed In the most suitable geological formation known to AEC involves short-term safety considerations which are preferable to the alternative of providing for the safety over many generations of numerous repository sites possibly located in less favorable geologic formations.

Transportation of any given quantity of wastes is a matter of days or weeks at most wile their safe storage is a matter of hundreds of thousands of years. Further, the technology and experience resulting from the transportation of irradiated fuel elements over the last 20 years provide a firm basis for developing safe, rellable systems for shlpping solidifled high-level radloactive wastes: 
Page 1e paragraph 3

Operationally it vould be desirable to reduce the distance for shipment of wastes by locating repositories in varfous regions of the country. Whether In fact this can be done will depend primar1ly upon whether suitable geologic formations extgt in such areas. This will be a mater for study during the comlng years. However, the fact remains that there is a current pressing need to establish an initial facility, and the AEC regards it of importance ihat this be ertablished where there is the greatest assurance of long-term safety. We don't anticlpate anything "to heppen geologically" at other. possible sites except that we hope to acquire nore information concerning thea. Ve do expect to acouire information through operations at the proposed Kansas repository wich will enable us to better determine what criteria should be considered in judging the sultability of other geologic formations.

\section{Page 2, first full paragraph}

With respect to the reference in your letter to the 1967 IAEA Renort, the "vlolent shattering of the galt" observed occurred in testing stall unconfined laboratory aamples at CRIL. During the Project Salt Vault demonstration in the Carey salt Company nine, euch shattering did not occur in the confincl salt surpondlng the hot fuel clements. llair-line-type fisures were noted only in the localized areas irmediately ajjacent to the burled waste contatners. The $200^{\circ} \mathrm{C}$, cemperature limit oroposed for the salt in the ming does no represent a threshoid teverature above which significant effects oil the confined sait could be expected. The Hroject Salt Vault scientists, pregently involvec in the design of the repository, have Indicated that higher temperatures could be tolerated in the salt vithout compronising the eafety of the facility. Whe $200^{\circ} \mathrm{O}$ liwit has been set as an appropriately conervative deblen parameter which is both safe and consistent with effective repository operation.

Hith regard to the gas 1 iberated in laboratory experiments, Dak Ridge Investigators have indicated that because of the minute quantities involved, the gas cculd not be analyzed. No problem with gas resulted during the Project Salt Vault. It should be noted, however, that it is the normal practice in the design of radio-chemical facilities to monitor and filter ventilation air before it is released to the environment. Consequently, in the unlikely event that elgnificant quantities of gas will be evolved, the alr cleaning system would assure that no radloactivity would be released from the facility in excess of existing radiation protection standards.

With regard to your request for additional information concerning "actual disposal of the wastes in the salt 1tself," the best we can offer 18 
Information pertaining to Project Salt Vault because, to date, no actual wastes have been placed in salt by AEC. An engineering report sumarizing the data obtalned in Project Salt Vault is presently being prepared for publication and should be avallable within one to two months. We will provide you a copy when this is avallable.

\section{Page 3, flrst paragraph}

The shipment of wastes from a commerclal fuel reprocessing plant to the repository would be arranged for and the cost of transportation borne by industry. AEC charges for handling, 6torage and survelllance of the wastes at the repository would assure full recovery of AEC's costa. These chargeg vould be collected by AEC from the companies owning the wastes.

In addition to payment of the purchase price to the owners of the land on which the proposed repository would be located, the state and locallty would have the economic beneflt of the substantial construction activity and the continuing operaticnal payroll. With regard to the effect of removal of the land from the tax rolls, AEC has statutory authority to rake payments in lieu of taxes to local authorities affected by euch a site acquisition.

\section{Page 3 , zecond paragraph}

We are in the procesa of compliling a great deal of information concerning the proposed project and site. This will be avallable to the public and w111 provide the basis for the Environmental Inpact Statement required by the Environmental Policy Act of 1969 and 18 currently under preparation.

I hope that AEC can reasonably assure you, other officlals of Kansas, and the general public that the proposed facility can and will be safely constructed and operated.

With regard to your question as to why Kansas should accept for etorage nuclear wastes frow other states, I offer the following suggestion: The proposed repository will be a natlonal faclilty, constructed to handle a national problem for which the AEC is seeking the best solution. We do not regard the facility as constituting a "dump" because that term belles the careful treatment that $w 111$ be accorded these expensive wastes. A few weeks ago the Kansas Nuclear Energy Councll, wthout any suggestion by AEC, voted to term the facility the Kansas Nuclear Park. The stated purpose of this action by the Councll was to discourage use of terms like "dump" and to recognize that the function of long-term storage of wastes is an Important part of the nuclear energy Industry. 
While at the moment Kanses may not have a large stake in the growth of nuclear power, it 18 doubtful that this condition 111 long continue. The fact that Kansas has a Counc1l on Nuclear Energy demonstrates State interest in a nuclear future.

The Nuclear Age and the ARC have not entirely bypassed the citizeng of Kansas. Located in Kansas C1ty. Miosour1 1s AEC's largest manufacturing facility, the Kansas City Plant, operated by the Bendix Corporation. That mlant employs some 7500 persons with an annual payroll of over $\$ 80,000,000$. About one-quarter of the employees live in the State of Kansas.

\section{Sincerely,}

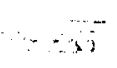

John A. Er lewlne

Assistant General Manager for Operations

Enclosure:

As stated 
Mr. Join Rislewine

Assistant General Manager

for Operations

Washington, D. C. 20545

Dear Mr. Erlewine:

$I$ want to thank you and Mr. O'Neill for discussing with ne on June 26, the proposal for an atonis waste repository at Lyons, Kansas. However, I wi.l be frank in tel.ling you that I. still have serious dollots about this project and would like you to answer a few more questions.

In our moeting and in an earlier letter, I asked you why kinsas was chosen as the site for this nuclear waste repository, and you answered that this was "based on the favorable geologic characteristics of the Kansas salt beds and our rather extensive monledge of the area." I would like to know if a comparative study has beon made contrasting the kunsas salt beds with other possible disposal sites such as the Salina Basin in the eastern United states. If there is such a study, is it available for my roview? I would also like to know if it is the opinion of the Atomic Encrgy Commission that the divantages of the Lyons site are so much greater than any other site closer to the source of nuclear wastes that these advantages justify the additional cost and risk of transportation of the wastes across half the nation. If this is the decision of the Comnission, what factors influenced this decision?

In vour letter to me of June 30 , you state that in addition to tire lyons repository the AEC "contemplates that in time there would be a total of four or five such repositories located throughout the United States." If Ransas is so geologically safe at this time as to justify a thousand-mile ship- 
ment to the Lyons site, what do you expeci to happen geologicaing to the other sites over the next few years to bo aijie to contemplate their construction, and - by impjication - their geological safety? It would socm to mo that if there are no major aifforences beiveen the sites which would prevent eventual storage, it would be to the advantage of the Atomic Fnergy Comisision and the safety of thousands of persons to locate an initial waste repository at a site much closer to the source of waste and thus reduce tine risks of transportation. llowever, if. there is sone unknown riajor factor which calls for experimertiatjon in the "safest" area (i.e. Kansas), even at the extra expense and added risk of transportation, then I would like to be carefully informed of that factor.

\section{In adoition to the above anstmexs, can you} provide ne vitin more adequate information relating to the acinal aisposal of the waster jn tine salt itself? J.r. "Disposal of Radioactive lastes Into the Growira," Rojort of the International Atomic Energy Acjency, vionia, 1967 , I read (at 555), "Soile bedued sali, inclueing that in Kansas, contains small amounts (icss than $1 / 2 \%$ ) of moisture in the form of smal intsacrystalline brine inclusions. Whis property had been assumod to limit the maximum allowable saj.t temperiture to less than $250^{\circ} \mathrm{C}$ : sirce, above tinat tomperature, internal vapoi prossure causes a vioient shattering of the salt." If the nuclear waste to be ceposited at Lyons reaches an estinated $200^{\circ} \mathrm{C}$, doosn't this create a danger within the mine area? In adaition, this paper also states (at 55i), "rhe only distinguishable effect of radiation so far duterinined has been the intermittent production of extremely small cruantities (less than Ippre in the off-gas) of an oxidizing gas. The gencration of this gas, which is not radiolytic chlorine nor hylrogen peroyide, appears to be a function of dose rate and dependent upon a tiresiold salt tempecature ö approximateiy $150^{\circ} \mathrm{C} . "$ What findings have the AeC uncovered in this respect? Furthermore, I reac at page 557, "with the present state of knowleage, it is impossible to predjot in detail all of the responses of the salt to any givon set of thermal conditions." Have studies been conducted by the AEC so that one may be assured that this last statement no longer holas true? Are these studies 
available for my review?

In rogard to the cost of transpontation and maintenance of the disposal facility, I. would like to know how the AEC proposes to porportion the cost of shipment of wastes and the cost of maintenance of the faciitty among the private industries. Will the AEC chisge the companies directly? In addicion, will kanses be compensated in any way other than by the purchiate price, For the land permanently retired Fiom her tax roles?

In conclusion, you kno: tinat I feel that since the effects of this project will extend for beyond the Iives of any of its proponents, I vould like to sec a sizais.e jibrary of accurate and indisputable facts comlided as assurance of the rod safety of this proposal. Finen, cven it safety can be reasonably assured, I Eind it difficult to understand why Ransas shoula accept the nuclear vash of private incustry joeated hundseds o: miles from hes: borders. Cur you tel I me why tre poople of kansas shoule assume tive risk of disposing of nuelear gathage mon they have not been offered one bonetit in tho way of production of niclear pover?

Fifty yones fron now, whon the ration is operating at fuli strengtin in the Nucjear Age, the polluting elomont -- the garbage of the mocom age -will be the very kind of wastes you wisli to ship to Kansas nom. It is a strange way to crter the Nucicass Age by beconing the gratbage pit for the nation.

\section{Sincerely,}

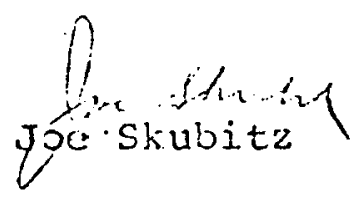


Honorable Joe Skubitz

House of Representatives

Dear Mr. Skubitz:

Ir. O'Ne111 and I appreclated the opportunity to meet and discuss with you the proposed project for construction near Lyons, Kansas of a repository for long-term etorage of solid radloactive wastes.

I am replying to your letter to me dated June 23 and will also coment on your letter to Governor Docking dated June 18. In addition, I wlll attempt to answer questions ralsed at our neeting.

In your letter of June 23 you ask: "Can you tell me if the AEC, before chosing kansas as a alte for a nuclear waste repostitory, requested permission to construct simliar facilities in Nebraska and Idaho? Did these states deny the $\mathrm{AEC}$ 's request"?

AFC has not proposed to congtruct the faltlal repository anywere but at Lyons, Kansas, nor has perulszion been requested of llebrastea, Idaho or any other state for establishrent of the repository. A3 I stated at our meeting. AEC has selected the kansas site bccause ve know of no better geologic area for such a repository and because we have more information about the Lyong ste than abour any other similar location.

Regarding your letter to Governor Docking:

Page 1, first paragranh - I agree with your position that the proposed project "cieserves careful consideration" and that approval of it "should not be given in haste, yet neither should we react out of fear." This position appears consistent with that adopted by the Kansas Nuclear Energy Counc1l "that the present AEC proposal be endorsed, subject to additlonal information."

In the Fact Sheet that. I left with you is a listing of further safety revievs involving the proposed project. From these studies will come additional Information and evaluation that should supply sound answers to remaining questions. 
Page 1, second paragraph - I don't belleve there is any inconoistency between the statement you quote from letter and the statement attributed to $\mathrm{Dr}$. Hambleton. There to extensive information concerning the Kansas salt beds. However, when one talks about a precise location, such es the mine near Lyons, there are always additional questions to be asked and answered. One of the reasons for AEC's selection of the site was to permit concentrating on a precise location. Dr. Hambleton has proposed a program to obtaln necessary geological information regarding the site and he has estimated that the program can be performed in $81 x$ months time. AEC is working with the kansag Geological Survey, the U.S. Ceological Survey, and other organizations to develop and carry out such a program.

Page 2, flrst paragraph - The effect of heat frow the wastes on the land surface, ground vater and adjacent underground areas, was dlscussed durlag our recent meeting. Calculations indicate that ti will take from 800-1000 years for the heat to reach the land curface and that even then cn conservative assumptions there would be only $1 \mathrm{~F}$ rise in temperature. Even that rise may not occur if ground waters are in motion below the surface. Th1s matter w111 be further studied dur ing the next few months.

Regarding heat effects on adjacent underground area, it is our latent to acquire underground rights aurounding the actual repository to a distance that wouli assure there is no effect on adjacent users.

Regarding safety of shlpwent of the wastes to the repository, I an enclosing some plctures and information regarding the shipplag casks and ATRX cars in whlch wastes would be transported.

Page 2, second peragraph - There 18 no speclal significance in the fact that the high level wastes would be coming from comeeclal power plants rather than Federal plants. AEC has been carrying out its statutory mandate to help create a comercial nuclear industry and to bring to an end the Governmental monopoly that exloted when AEC was established.

As I informed you at our meeting, AEC will charge industry for the full cost of storage and perpetual care of conmerclal vastes stored la a Federal repository.

We also discussed the fact that the proposed atorage facllity near Lyons would be the initial Federal repository and that AEC contemplates that in time there would be perhaps a total of four or five such repositories located throughout the United States. Thus, although the proposed Lyons reposttory would have the capacity to handle all comercial waste for the 
next twenty-five years, in practlce, 1ts operatlonal lifetime might be considerably longer as other repositories come into operation.

If you have other questions regarding the proposed repository. I would be pleased to try to answer them.

\author{
Sincerely, \\ TOMN A. EYUENINE \\ John A. Er lewine \\ Asslotant General Manager \\ for Operations
}

\title{
Enclosures
}


SKUUBITZ

5TH DISTRICT, KANSAS

COUNTIES:

GREENWOOO

HARPER

LABETTE

LINN

LYON

MONTGOMERY

NEOSHO

OSAGE

SEDGWICK

SUMNER

WILSON

\section{Canuress af the finited States}

䅣ouse of Ziepresentatiues

celasłington, Z.C. 20515

June 23, 1970
COMMITTEES:

InTERIOR AND INSULAR AfFAIRS

INTERSTATE AND

ForeIGN Commerce

Mr. John A. Erlewine

Assistant General Manager

for Operations

U. S. Atomic Energy Commission

Washington, D. C. 20545

Dear Mr. Erlewine:

can you tell me if the AEC, before chosing Kansas as a site for a nuclear waste repository, requested permission to construct similar facilities in Nebraska and Idaho? Did these states deny the AEC's request?

As you perhaps know, I have some grave doubts about this project. I am enclosing a copy of a letter which I sent to Kansas Governor Robert B. Docking expressing my concern for the true safety of the proposed atomic waste repository tenatively selected for Lyons, Kansas.

Sincerely,

Joe Skubitz 


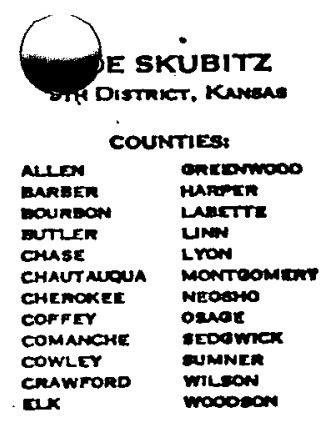

\section{Cangress of the Anited tates \\ 复ouse of 3epresentatibes}

20singtom, 20515

June 18,1970

Honorable Robert B. Docking

Governor of the State of Kansas

State House

Topeka, Kansas 66612

Dear Bob:

Yesterday the Atomic Energy Commission announced the tenative selection of Lyons, Kansas, as the initial site for an atomic waste repository. The commission will soon seek authority from the congress for the initiation of this 25 million dollar, 1200 acre project. It is my feeling that a proposal such as this deserves careful consideration. An approval should not be given in haste, yet neither should we react out of fear.

As a representative for kansas, I join you in your cautious concern for the safety and welfare of all Kansas citizens. I have grave doubts about the true safety of this project in view of the many differing facts and conflicting opinions on the safety of nuclear waste disposal. For a project whose effects will extend thousands of years into the future, indisputable answers are needed to some serious questions. For example, is enough really known about the geology of the region? In a letter to me on June 11, John A. Erlewine, Assistant General Manager for operations of the Atomic Energy Commission said, "Consideration of Kansas as a site for the initial demonstration Federal waste repository is based on the favorable geologic characteristics of the Kansas salt beds and our rather extensive knowledge of the area." Yet in the wichita Eagle, June 10, Dr. William Hambleton, Director of the State Geological Survey at the University of Kansas is reported to be concerned over the lack of specific geological information. He says, "We simply don't have enough information on the geology of this region.". 
Furthermore, in response to my letter of May 28 , Mr. Erlewine assures me that the great magnitude of heat to be generated from the wastes in this mine will have "...no adverse effects on the surrounding environment." Yet in the Wichita Eagle, June 10, I read, "Estimates are that the surface temperature will rise 14 degrees centigrade above the more than 800 acres which top the proposed storage area." Will there or won't there be heat which will effect the environment? will this "great magnitude" of heat not effect the water in adjacent underground areas near Lyons, Kansas? These questions need positive, satisfactory answers. I want to be assured, as I am sure you do, that the heat produced by these nuclear wastes will not affect one acre of Kansas soil. I want to know positively that my grandchildren's children will not be harmed by the effect of this "repository" under such unforseen circumstances as a shift in the earth's crust. And I want accurate proof that not one of the 300 cannisters of waste to be shipped each day will break open in an accident en route to Lyons, Kansas. These facts -- and many others -- must be proved with far more accuracy than the facts which "proved" the Titanic "unsinkable." And finally, Governor, we should know if the state of Kansas will be allowed complete control over the amount and kind of wastes to be deposited in years ahead. Will kansas be allowed to say "no" when it has had enough of these wastes?

In the final analysis, it seems to me that we are being asked to assume unknown risks to make kansas a nuclear dumping ground for all the rest of the nation. In addition, the wastes will not even be coming from federally-owned nuclear power plants. I am told in another letter from Mr. Erlewine of the AEC, May 11, 1970, that, "It is contemplated that most of the high level solid waste would come from privately-owned fuel reprocessing plants." Is Kansas to become the garbage pit for private industry in other states? The state of kansas, which has not contributed one micro-curie to the growing heap of atomic waste material from fuel reprocessing plants, is being asked to take all of these wastes as a"repository" in the heart of her prarie land. This seems a high price to pay for a mere dumpyard which will only provide 200 jobs, yet will be around for half a million years. 
My best personal regards,

\author{
Sincerely, \\ atabl \\ Joe Skubitz
}


Honorable Joe Skubitz

House of Representat Ives

Dear Mr. Skubltz:

This is to Inform you that the Atocic Energy Commission has tentatively selected a site near lyons, Kansas, for an initlal salc mine repository for the denonstration of long-term atorage of solid high-level and long-lived low-level transuranium waste.

Enclosed is a copy of a public announceixent giving detalls of the proposed project. It is planned to distribute this announcenent to news medla at 2:30 PM (E.DT) today, Wednesday, June 17.

This matter has been discussed with appropriate officials of the State of Kansas.

If we can be of further assistance in furnishing information on this project, please let us know.

Sincerely,

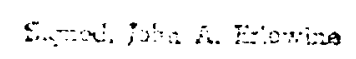

Enclosure:

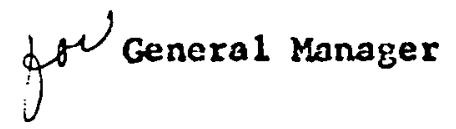

Public Announcement 
June 11,1970

Honorable Joe Skubltz

House of Representatives

Dear ifr. Skubitz:

In response to your letter of hizy 28 , 1970, we are pleased to provide in the caclosure to this lecter, answers to the questions you have raised in conaction with the establinhment of a lederal Repository for radioactive wasces.

If thore are any additionil questons vidich come to rind as a result of your rovien of this incorntion, please let us knot and we vill be hapy to provice you utin witever aditional informition you mis reguire.

\section{Sincorely,}

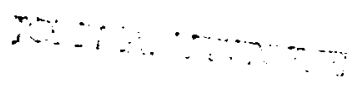

John A. Erle::rna

Assigtant Genazal Hanger

for oposations

Enclosure:

Answers to Ruestions Reised

in duy 23, 1970 letter 
Response to the Questions Raised by

Congressman Skubitz

Question 1: Can you estimate the energy production of the entire amount of waste to be stored in this mine and its dependence on time; i.e. the wattage of the waste as a function of time?

Question 2: What do you estimate will be the specific energy production of the waste, i.e. the wattage of the waste per unit volume as a function of time?

Question 4: What do you estimate will be the "life-time" of the mine; that is, when will it become filled to capacity and be sealed-up?

The production of thermal energy within the salt repository will be essentially a function of the lifetime of the facility. It is presently anticipated that this repository will have an active 1 ife of about 30 years at which time it will contain wastes which will generate less than 1000 megawatts of thermal energy. This heat generation, however, is only of significance in relation to its effect on the salt bed, i.e., the extent to which this energy will raise the salt temperature. In defining the design criteria for the repository, the experience obtained in the field engineering demonstration carried out in an abandoned mine in Lyons, Kansas, has indicated that the temperature of the salt should be limited to a maximum of $\sim 200^{\circ} \mathrm{C}$. This limit was established primarily on the basis of conservative engineering considerations related to maintaining the integrity of the active mine workings during burial operations. In order to assure that this temperature limit will be maintained, the heat generation in any one container will be limited to a maximum of 5 kilowatts and the containers will be buried in a carefully defined pattern.

Because salt is a relatively good heat transfer medium, decay heat will flow from the mined area and dissipate in the parent salt bed. Temperatures will thus be higher in the center of the mined out area and will decrease with increasing distance from the center of the facility. Computer calculations based on heat transfer data obtained in the Lyons demonstration indicate that the maximum temperature in the bed (i.e. $200^{\circ} \mathrm{C}$ ) will be reached after $\sim 30$ years of mine operation and will decrease very slowly as the radioisotopes decay. Maximum temperatures in the mine after 500 years will be on the order of $100^{\circ} \mathrm{C}$ decreasing to $\sim 50^{\circ} \mathrm{C}$ after 2000 years. Analyses performed thus far indicate there will be no adverse effects on the surrounding environment resulting from a temperature increase of this magnitude. 
Question 3: How will the mine be cooled? by air-ventilation?

The decay heat generated in this facility will be removed by and dissipated in the salt itself. Air supplied to the mine workings will essentially be for the support of operating personnel. Although ventilation air will provide some ninimal cooling, these effects will only be temporary since each working area will be backfilled with crushed salt as soon as operations are completed. In a relatively short time, the crushed salt, under the pressure of the overlying rocks, will recrystallize, eventually sealing off the entire mine area.

Question 5: Why has Kansas been chosen as a depository site when it is so far from the reprocessing plant in New York and the proposed plants in Illinois and South Carolina? Doesn't this present undue transportation problems? Aren't there disposal sites in the salt beds of New York State?

Consideration of Kansas as a site for the initial demonstration Federal waste repository is based on the favorable geologic characteristics of the Kansas salt beds and our rather extensive knowledge of the area. These characteristics relate to the thickness and quality of the salt, the depth to the disposal horizon and the stable geologic history of this region. While it is true that a salt repository could conceivably be located in the salt beds of New York State, we believe that the geologic characteristics of the Kansas salt beds are generally more favorable than those of the salt in the Salina Basin which underlies portions of Michigan, Onio, Pennsylvania and New York. Such locations as well as the salt domes along the coast of the Gulf of Mexico, may well be considered for future waste repositories. With respect to the transportation of these wastes from the fuel reprocessing plants, the technology and experience resulting from the shipment of highly irradiated fuel elements over the last 20 years provide. a firm basis for the development of safe, reliable systems for shipping solidified high level radioactive wastes. Transportation of these wastes to a central repository would be carried out in strict compliance with existing regulations of the AEC and the Department of Transportation and should not therefore endanger the health and safety of the public. Additionally, locating a repository in Kansas would tend to equalize the distance over which wastes would be transported. For example, a repository in central Kansas would be approximately 1250 miles distant from the Nuclear Fuels Services plant in New York, 1200 miles from the Allied Chemical's Barnwell plant in South Carolina and 1200 miles from a hypothetical plant located in central California. 


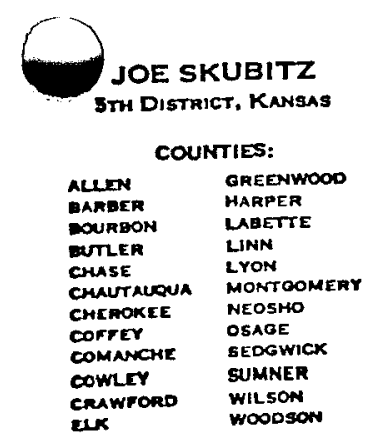

\section{Condress of the Anited States \\ 囱ouse of 3 epresentatibes \\ 20lasfington, Z.C. 20515 \\ May 20, 1970}

Dear I.r. Erlewine:

I have a few more questions which I hope you can answer regardins the proposed construction and operation of a storace facility for . solid radionctive wastes in the salt beds of contral Kansas.

1) Can you estimate the cnergy production of the entire amount of vaste to be stored in this mine and its dependence on tirm; i.e. the vattage of the vaste as a function of time?

2) That do you estimate rill be the snecific onergy pronluction of the vaste, i.e. the wattace of the vaste per unit volume as a funetion of time?

3) How will the mine be cooled? by air-ventilation?

4) What do you estimate vill be the "life-time" of the mine; that is, when will it become filled to copacity and be sealed-lup?

5) Why has Kunsas been chosen 35 a depository site when it is so far from the reprocessing plant in $N$ lew york and the proposed clants in Illinois and South Carolina? Doesn't this present undve transportation problens? Aren't there desposal sites in the salt beds ot liew York State?

Awaiting your reply, I an

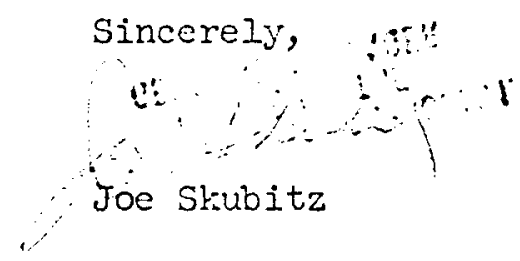

A.r. John A. Erlewine

Assistant General Manager

for Operations

U. S. Atomic Energy Comission

Washington, D. C. 20545 
Honorable Joe Skubitz

House of Representatives

Dear Mr. Skub1tz:

'This ts in reply to the questions ralsed in your letter of May 4, 1970. Please understand that my answers must be qualifled in nature because the exact location of the proposed facility has not been designated nor has the necessary engineering design work been performed that would permit more precise numerical values.

1. What is the proposed size of the initial depository?

A: Approximately 1200 acres of land would be Involved.

2. How much waste do you anticipate will be stored in the area in the next flve, ten, twenty years?

A: H1gh Radiation Level Solld Wastes - The faclity is expected to be able to store all wastes of $\operatorname{th} 18$ type generated by the comercial nuclear power Industry for about 20 years.

Our best estimates of these quantities are as follows:

$$
1980 \quad\left(\ln \frac{1990}{\left.\mathrm{cu}^{\mathrm{ft} .}\right)}\right.
$$

2000

Annual Volume

10,000

33,000

58,000

Accumulated Volume

44,000

290,000

770,000

Approximately 830 acres of mine area would be required to provide the proper spacing for storage of the wastes.

Low Level Solid Nastes - It 18 anticlpated that approximately 40,000,000 cubic feet of storage space would be provided. The design concept would provide a handling capability of approximately 1,000,000 cubic feet per year. 
3. Is the waste to be stored accumulations from private concerns operating plants using reactor fuels? What companies would be Involved?

A: Yes, it is contemplated that most of the high level solfd waste would come from privately-owned fuel reprocessing plants. At present there 18 only one such plant in operation. Th1s is the one located in New York State and is owned by Nuclear Fuel Services, Inc. The General Electric Company is building such a plant in Illinois and Allied Chemical Company and Atlantic RIchfield Company have announced plant for bullding plants in South Carolina. It would be reasonable to assume that other plants would be required before the year 2000 .

4. What bothers me is the following quote from your letter -- "AEC Would plan that the salt mine would be the initial repository." Does this mean trash accumulation will be sent to Kansas and gtored for a perlod of ten years or that it wlll be stored somewhere else for ten years and then sent to Kansas?

A: It means the latter. The wastes w111 be solidifled and stored at the fuel reprocessing plant for up to ten years before shipment to the repository. Once at the repository, it is anticlpated they will remain forever. By "Initial repository" 18 meant that in time there are expected to be other repositories.

5. Will all low-level radioactive waste accumulationg of the AEC be shipped to the repository? How mach waste has already been accuroulated by AEC?

A: It 1s presently contemplated that only those low-level solid AEC wastes that are contamlnated with radioactive materlals having a long life-time would be sent to the repository. At present our facllltles generate perhaps $500,000 \mathrm{cu}$. ft./year of such wastes. A few million cublc feet have been accumulated and some portion of these would be transferred to the repository.

6. WIIl additional facilities be constructed? How many permanent jobs wlll this project provide?

A: The Initial facility would provide for storage of both high-level and low-level wastes. The inftial facllity may cost about $\$ 25,000,000-35,000,000$. It could be anticlpated that some 
additlonal construction might be required during the life time of the facility.

The size of the work force will, of courge, vary with the activity of the facility but is expected to reach about 200 persons.

I hope that these answers are responsive to your questions. I would be pleased to meet with you and further discuss these matters.

Sincerely yours.

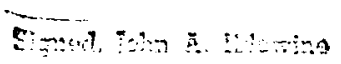

John A. Er lewine

Assistant General Manager

for Operations

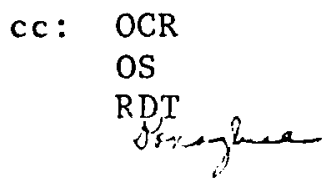


COUNTIES:

殖ouse of 3iepresentatibes

ratabhington, Z.C. 20515

May 4, 1970

Dear Mr. Erlewine:

This will acknowledge receipt of your letter of April 24, 1970, regarding the construction and operation of a storage facility for solid radioactive waste in the salt beds of central Kansas.

What is the proposed size of the initial depository? How much waste do you anticipate will be stored in the area in the next five, ten, twenty years? Is the waste to be stored accumulations from private concerns operating plants using reactor fuels? What companies are involved? I note that you say, "They (who?) would isolate the fission products from the fuel and after storing such wastes ...wold ld be required to solidity such wastes and ship them to a waste repository." what bothers me is the following quote from your letter, "AEC would plan that the salt mine would be the initial repository." Does this mean trash accumulation will be sent to Kansas and stored for a period of ten years or that it will be stored somewhere else for ten years and then sent to Kansas?

on page 2 of your letter you state, "Although I did not discuss this during our telephone conversation, in addition to the highly radioactive wastes described above, we would plan to also store certain other solid wastes that have been contaminated with low level radioactive materials." Do I interpret this to mean that all radioactive waste accumulations of the AEC are also to be shipped to kansas? How much waste has already been accumulated by the AEC? Is it the intention of AEC to ship all of this to Kansas? If so, will add- 
itional facilities be constructed? How many permanent jobs will this project provide?

Awaiting your early reply, I am

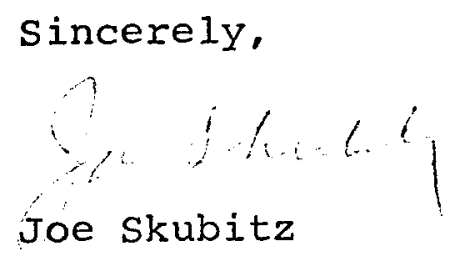

Mr. John A. Erlewine

Assistant General Manager

for Operations

U. S. Atomic Energy Commission

washington, D. C. 20545 
Honorable Joe Skubltz

House of Representatives

Dear Mr. Skubitz:

Confirming our telephone conversation on April 23, 1970, the Atomic Energy Comission is giving conslderation to geeking in connection with the FY 1972 budget, legislative authority and funding to construct and operate a storage facility for solid radicactive vastes in the salt beds of Central Kansas. AEC representatives have discusged these tentative plans with Governor Docking, hepresentailve Shriver and gtaff newbers of Senators Dole and Pearson, all of whom have encouraged AEC to proceed with these plans.

Such consideration is based upon the results of several years of extensive research and testing carried out by $\triangle E C^{\prime} s$ oak Ridge hational Laboratory in the Carey Salt iatne near Lyons, cansas. This progran, called Project Salt vault, utilized highly radicactve reactor fuel clenents to sijulate heat and railation such as would cone from solidified radioactive wastes. Results of project Salt Vault show that a storase facility located approximately 1000 feet below the earth's surface in the Central Ransas bedded salt formations would be in as safe a geologic formation as can be found in the linited states. Such a facility would be 6afely 1solated fron fresi water aquifers for geologic perlods of tine and offer effective protection agalnst accidental contact by man or animals.

High level wastes that would be stored in such a facllity would cone from fuel reprocessing plants located throughout the country. Such plants would process spent reactor fuel elements to recover unconsumed enriched urantum and plutonium. They would isolate the fission products from the fuel and after storing such wastes on site for a period probably not in excess of 10 years, would be required to solidify such wastes and ship then to a waste repository. AIC would plan that the salt mine would be the initial repository. Such shipwents would be made in special casks on rallroad cars that are designed and constructed to safely contain the wastes even in the event of a severe raflroad accident Involving prolonged immeraton in fire and water and Involving a severe drop or coll1日100. 
Although I did not discuss this during our telephone conversation, In addition to the highly radioactive wastes described above, we would plan to aloo store certain other solld wastes that have been contarinated with low level radioactive materials. At present such wastes are stored in near surface burlal grounds at AEC facilities.

Only solid wastes would be stored in the salt mine facility and only solld wastes would be shipped there. Processing of liquid wastes to solid form would be performed before shipment to the salt. mine.

I believe that the foregoing represents in summary what I told you on the telephone. I would be pleased, if you so desire, to meet with you personslly and discuss the matter in greater detall.

The Comisston has not yet made a dectsion on this matter, and I have promised Governor Docking and members of the Kansas Congresolonal delegation that $A E C$ would coordinate with them before announcing its plans regarding the salt mine. I hope the foregoing Is rosponsive to your request for information.

Sincerely yours,

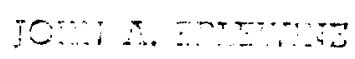

John A. Erlewine Assistant General Manager for Cperations 